
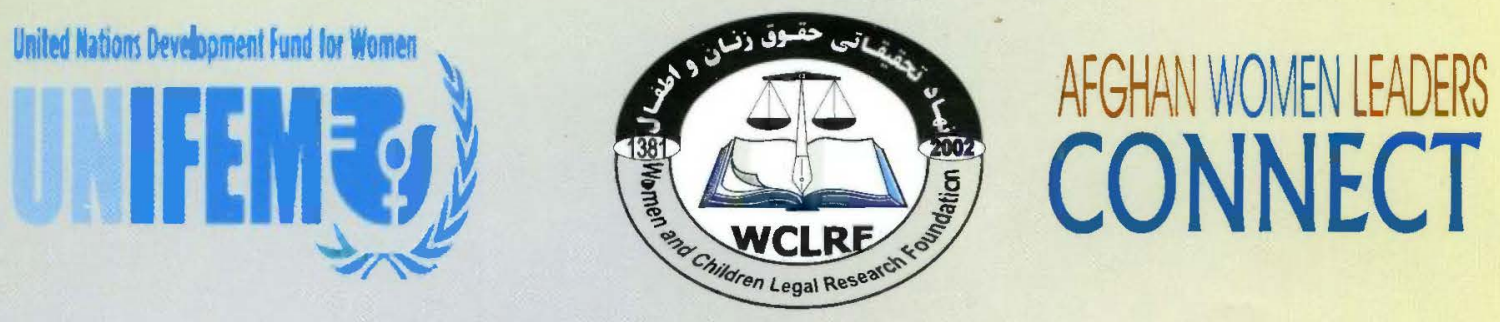

\title{
Impact of traditional practices on women
}

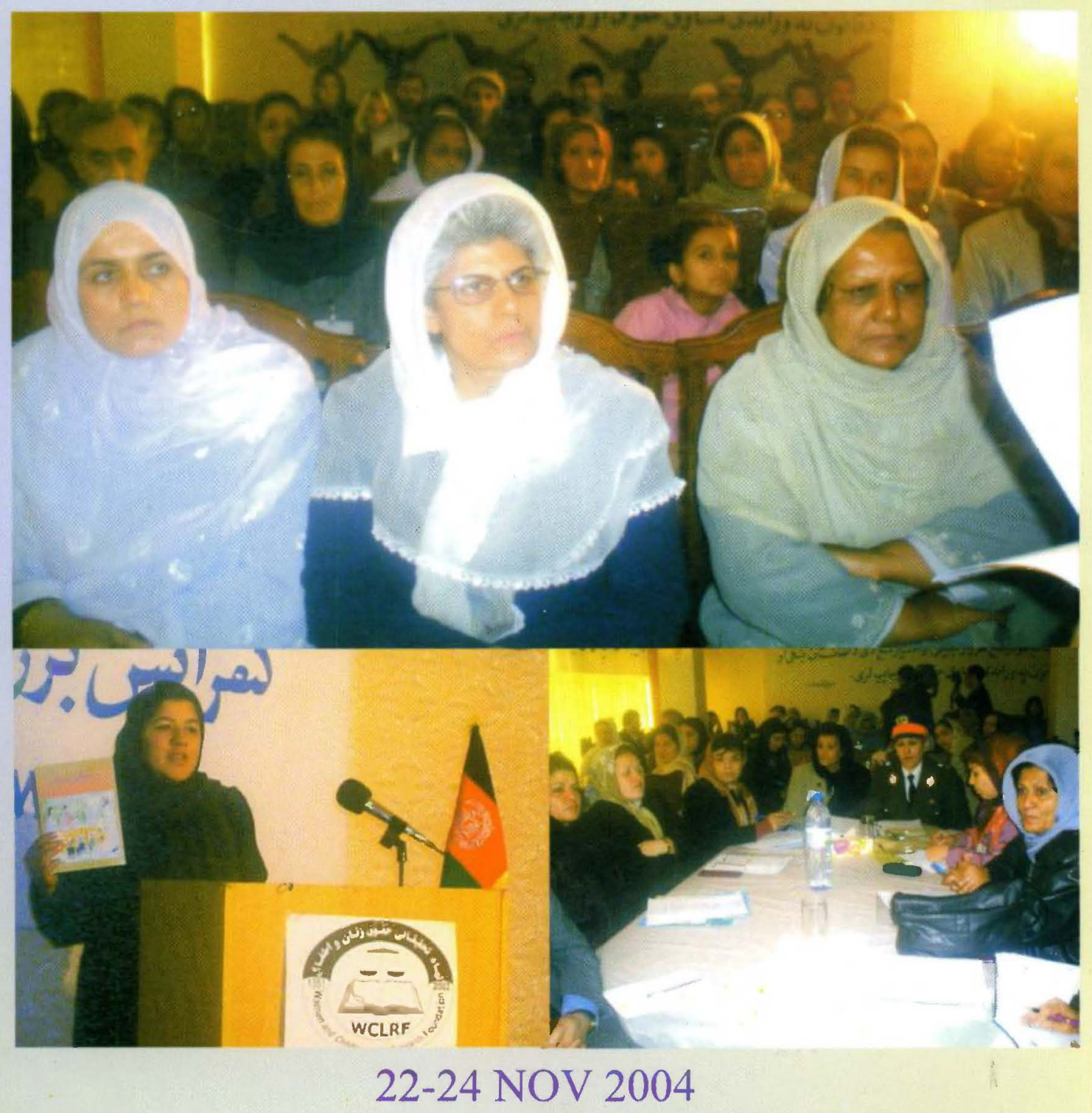




\section{Impact of traditional practices on women}

\section{Table of Content:}

First Chapter

Preliminary Session

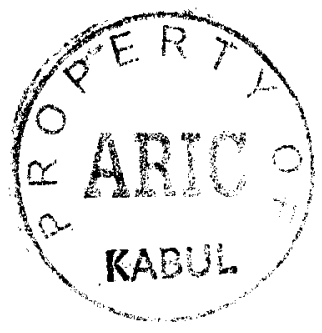

1. Introduction of Organization.....................

2. A bout the Conference...........................2

3. Method of Conduct...............................

4. Criteria for Selection.............................

5. Conference Achievements......................4

6. The Importance of Conference...................5

Second Chapter

First Session

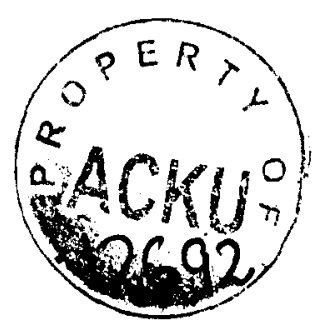

General Conception of traditional Practices and its Impact on Women

1. Islam and Traditional Practices....................6

2. Human Right \& Traditional Practices..............9

3. Legislation \& Traditional Practices................13 


\section{Impact of traditional practices on women}

4. Goverement \& Traditional Practices................ 14

5. Justice \& Traditional Practices..................16

Second Session

Traditional Practices in Afghanistan and its Impact on Women Right

a. List of Traditional Practices regarding women....... 18

b. Analyzing the Most Common Traditional Practices... 19

c. Decision Making Structures.....................26

d. Proposed Solutions............................29

Anncxes

1 - Speeches

1.1. Dr. Surya Subrang. Deputy Minister MoWA.........30

1.2. M. Farid Hamidi, Commissioner AIHRC .............35

1.3. F.^. Manawi, Deputy Chief Justice................38

1.4. Dr. Rangeen Dadfar Spanta, Law Proflesor..........42

1.5. Judge Q.Kashaf, Head of Civil Court................47 


\section{Impact of traditional practices on women}

1.6. Dr. Zekria, Commissioner, JRC ......................50

1.7. Amina Afzali, Commissioner, AIHRC ...............52

1.8. Najia Zewari, Senior Program Officer, UNIFEM.....54

2- Resolution........................................57

3- Agenda..........................................60

4- List of Participants..............................62

5- List of facilitators................................65

6- Task Force Members..............................65

7- List of Speakers.................................65

8- Nomination Form...................................66 


\section{First Chapter}

\section{Preliminary Session}

\section{1..Introduction of the Organization}

The Women and Children Legal Research Foundation (WCLRF) as one of the professional organizations in the area of women and child right was established in the year 2002 with the efforts from a group of women lawyers in Kabul city.

The main reason for the establishment of WCLRF was the universal debates made around the living situation of women and children in Afghan society.

In all these debates the issue of traditional practices stood as one of the main factors for violations to the women right. But in a war effected country like Afghanistan which relay mainly on traditional customs and people practice such customs as part of their believes; there is a limited number of individuals who believe that these customs are brining many violations to the life of women and children in Afghanistan.

This issue was the main reason which establish the foundation of WCLRF; and the founders of WCLRF started working on the above mentioned issue voluntarily, and their aim was to primarily collect the facts and figures proving the presence of the violation inducing traditions which are catastrophic for women and children and secondly they should highlight the role of governmental 


\section{Impact of traditional practices on women}

institutions who are anyhow involved in bringing the change in this regards, but now playing the role of silent audience.

In fact WCLRF was established to struggle against the injustice and obstacles towards women and children rights which needs programming in short and long term; WCLRF was founded to provide human right defenders with reliable documents and facts in order to prove the traditional practices as a means of hardship towards women and children life.

\section{A bout the conference:}

The last week of November was the week to celebrate the struggles opposing "violence against women", which was commemorated world wide including Afghanistan. As mentioned, some of the traditional practices have been known as tools for violating women rights; thus the conference held by the WCLRF was mainly focusing tradition induced violation against women rights. The conference aimed to hold a national discussion about the impact of traditional practices on women life in order to highlight:

a) The types of traditional practices,

b) Impact of each of them on women's life,

c) Methods to prevent volitional tradition.

The conference was financed by UNIFEM and Afghan Women Leaders Connect and was coordinated with Ministry of Women Affairs, Afghan Independent Human Right Commission (AIHRC), Afghan Women Network (AWN), Foundation for Culture and civil Society (FCCS), AREZO office in Kabul and 


\section{Impact of traditional practices on women}

the distinguish individuals; Sayd Masoom Badakhsh, Najia Hanifi, Shila Samimi, Khadija and Jawed Danishyar.

\section{Method of Conduct:}

In order to conduct the conference effectively, a task force committee was formed of representative from the ministry of Women Affairs, AREZO Office and one of the advisors from the WCLRF. The committee was assigned for over all management and supervision of the program.

The main responsibility of the task force was the selection of participants, accomplished through a few step process. First 20 provinces were selected based on criteria which could cover all the country, secondly the organizations with wide coverage in the selected provinces were contacted; in the third step, questionnaires and nomination forms were developed and sent out to the provinces through the selected organizations (Afghan Independent Human right Commission (AIHRC). Foundation for Culture and civil Society (FCCS) and AREZO Office. (The questionnaire is attached)

In order to have the best participants, each province was asked to nominate 3 candidates for each allocated seat (two seat were allocated for each province) the nominees were to fill out the questionnaire which had to be reviewed by the task force in Kabul on the bases of which the selection were made.

A total number if 60 people were nominated from 20 provinces and based on the criteria 28 were selected, which were consisted of following categories:

1. Representatives from civil society, Government officials and respective people from each province, 


\section{Impact of traditional practices on women}

2. Civil society representative and Government officials from Kabul

3- Representatives of the related Government departments

4. Journalists

(List of participants is attached)

The conference was continued for three days from 22 to 24 November 2004.

The first day of the conference mainly comprised the speeches from the official representatives of the related organizations aiming to clarify the consequences of the traditional practices and the responsibility in this regards, which was continued by discussion s among the participants and speakers.

The second day of the conference was allocated mainly for group works and discussions among participants and the objective was to provide an opportunity for exchange of opinions and also to analyze the traditional practices existing in different parts of the country and also to seek solutions for such practices. The third day of the conference which was the last day designed mainly for drafting the conference declaration and also to present the declaration to press and audience from the related government officials, also the last day of the conference we lunched the research report on "Bad painful Sedative" (the research report on one of the traditional practices applied on women). During the conference a movie and a theatrical piece were displayed to participants about the practice of "Bad" (exchange of women for dispute settlement) and the issue of "stoning" (punishment for committing adultery). 


\section{Impact of traditional practices on women}

It is worth mentioning that the declaration was announced in the conference and was signed by all participants and also a representative from Supreme Court signed it on the behalf of Supreme Court. (Conference agenda is attached)

\section{Criteria for Selection of Participants:}

A set of criteria were develop by the task force committee for selection of participants, which are as follow:

1. The head of the organization should not nominate her/him self;

2. The participants should be aware of the existing traditional practices on their neighborhood;

3. The participants should be a well known personality in the neighborhood;

4. Male candidates should be a member of local councils.

\section{Conference Achievements:}

With the fact that the traditional practices exist in the most parts of the country and have their own importance among the public and vast sections of the rural areas, are managed by such structures; holding a national conference and claiming that most of these traditional practices are violating the rights of women; in itself is a big step. Bellow is a short summary of main achievements of the conference:

1. The Supreme Court announced its support

for the declaration of the conference, and declaration officially,

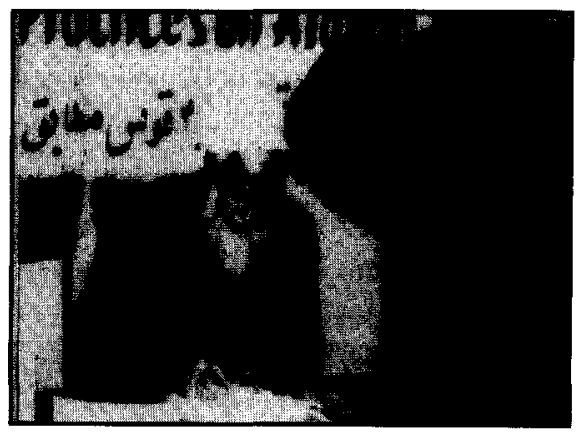




\section{Impact of traditional practices on women}

2. The ministry of Women Affairs has also confirm the

importance of conducting such program and they office-

-ially signed the declaration,

3. The public in Kabul and other provinces appreciate the effort of organizing such programs,

4. The issue of traditional practices and its impact was broadcast through the media circle; radio channels and press and websites,

5. The declaration of the conference was signed by participants of all other gatherings conducted by Ministry of Women Affairs for celebration of 25th of November and also a representative from WCLRF was invited in all these events to explain the findings of the conference to participants,

6. The declaration was confirmed by representatives from Afghan Independent Human Right Commission (AIHRC), Afghanistan Supreme Court, Judicial Reform Commission (JRC) and other related government departments and the representatives from more than 20 provinces of the country. 


\section{Impact of traditional practices on women}

\section{The importance of the Conference:}

The conference on the "Impact of traditional practices on Afghan women" has proven its high importance in such a critical time of reform and rehabilitation of the country, which can be summarized as bellow:

a. The outcome of the conference can be taken seriously in to account by the JRC and other organization that are supporting Judicial Reform process in Afghanistan in order to bring positive changes in the legal framework and confirm the unlawfulness of the traditional practices violating women right as a short term impact.

b. In the long term perspective, as the rule of law can be applied all over the country the informal justice (local councils) system should be provided with a framework of operation and there should be a mechanism of accountability developed for the decisions taken with the local councils. 


\section{Impact of traditional practices on women}

\section{Second Chapter}

\section{First Section \\ General conception of traditional Practices and its Impact on Women}

The traditional practices has a longer age than the rule of law in almost all societies. and once upon a time it was known as the only source for applying rule of the law, although there is ages of introducing the written law to communities but still traditional rules and practices has their own applications, and transfer from one generation to another generation over centuries.

Although there are a number of traditional

practices which are contrary to human rights

principles, there are also a number of tradition-

-nal ractices which form the foundation $\mathrm{f}$ human

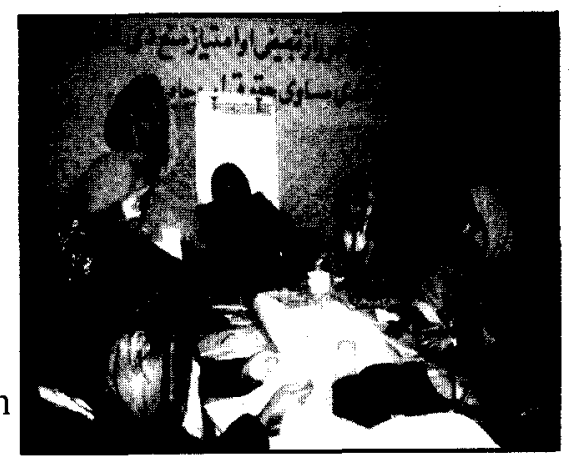

right principles and is confirmed nationally and internationally.

The participants of the conference tried to analyze only the set of traditional practices which is against the principles of Islam and Human Right. So, what you will read bellow is the summary of the discussions and speeches of the 


\section{Impact of traditional practices on women}

conference with the focus on the practices which violate women rights in Afghanistan.

\section{Islam and Traditional Practices:}

The tradition means "Anana" in Arabic which is confirmed in Quran (the holly book of Muslims). Based on historical views when Islam emerged there were a number of traditional practices existing in societies contradicting Islam, but also there were a number of practices which had nothing against Islam.

The number of customs and practices which were not contrary to Islan were named as "Marrof" and confirmed by Islam*, but those practices and customs which were against Islam were rejected by Islamic rules and Muslims were forbidden of such practices. As an example "burying alive the newborn girls" (the ancient Arabs considered the birth of a baby girl as a sign of shame so by the time a baby girl was born they were burying her alive) and this action was strongly condemned and prohibited by Islam.

Meanwhile there were lots of efforts to confirm the great importance and position of women in Muslim societies since many of the reliable historical documents present number of "Hadith" (speeches and guidance from Prophet Mohammad) through which all the effort is put together to change the mentality of the society towards women.

For instance:

Someone went to Prophet Mohammad (PBUH) and asked who is entitled of respect more than every body in the world, Prophet (PBUH) told: the Mother; the person asked the question three times and received the same answer and in the forth time he got this response: the Father. 


\section{Impact of traditional practices on women}

It is worth mentioning that the response given above is not a personnel view of a writer, poet... but it is the words said by Prophet Mohammad (PBUH) and it is clear that what he says is the words of Quran and Quran is the message from the God. As Quran says: "The Prophet Mohammad (PBUH) instructs us on what he have been instructed to say by God."

Also in another Hadith:

Prophet Mohammad (PBUH) told to Omar (the second Islamic leader after Prophet Mohammad) go and ask a person by the name of Wais Qarani to pray for you to the God. Omar was surprised and went there but asked from Wais that you are not close to Prophet and you are not a Suhabee (the people close to Prophet who are quoting directly from Prophet words) so how it comes that Prophet ask me to seek pray from you, and Wais replied: I am not close to prophet and I have never met him but once when I wanted to go and meet him I refused going there as I had to serve my Mother.

Also we know that there is an Islamic rule that in marriage time the groom has to

a sum of money to the bride as a property for her which called "Qentar" in Arabic, this issue is an Islamic custom which turn to be an important Islamic rule today, so on the issue of right of speech in the public for women, it is told that:

Once Omar the second Islamic leader after prophet Mohammad, was talking about Qentaar in Madena city and advising that women should take less money and property for Nekah (marriage), a women stood up and said: In Islam we have right to Qentaar (lots of property to receive for Nekah from groom) how do you dare to say that we should get less. And Omar told yes I am mistaken and you are right. 


\section{Impact of traditional practices on women}

This story shows that although Omar had a very high position and the women was only an ordinary women but still as Islam gives equal rights to men and women of all types so Omar confessed that she was right and he was wrong.

Looking to the above mentioned examples we can clearly say that Islam in its fundamental rule and principles is not contrary to the equal rights of women with men and is against all kind of violations towards women. also the precise instruction of Islam as in Holy Quran in Sorat Alnessa, verse 19 and Sorat AlBaqara, verse 23 concerning the prohibition of all kinds of hardship towards women clearly states that Islam is against the traditions which violate women's rights and the traditions applied on women does not have any root in Islam and is in contrary to Islamic guidance.

But unfortunately every day we are witness of applying hard traditional practices on women which is not less than the "live burial" in early Arab time (before Islam).

Based on the statements and information made available to the participants of the conference in the first day, the participants pointed out some of the practices example of conflict between what Islam has guided Muslims and how these gaudiness are against traditional practices applied on women; as below is some examples.

\section{Maher:}

As the justification for getting (Maher) from an Islamic point of view has been described above; but the way this issue is applied in societies is very much different form its original logic, based on which the bride family received a huge amount from the groom family, the bride herself will never receive the amount. 


\section{Impact of traditional practices on women}

So asking for such amount and receiving such amount is totally unlawful based on Islam, unless the girl (bride) agrees to take the amount or unless she wants to give the amount to her family or anybody else.

\section{Badal:}

Also it is a traditional practice and also it is very much common that in order to reduce the cost of marriage, the two families exchange the girls between each other, this way they want to get rid off paying "Maher". Based on practical examples the impact of such practices is very awful to both families. which will be described later on. Also it is worth mentioning that marrying the two girls at the same time from two families is not prohibited in Islam but the conditions that each marriage should count as a separate process and they should not be linked to each other by any means and they should have separate Mahers and separate marriage formalities.

\section{Bad:}

The practical way of applying this tradition is that to settle disputes among two families which caused from fighting, killing, payable dets.... A girl from the accused family is given to the victim family based on a decision made by both families, local council, influential individuals... To do such action there is no any source in Islam as in Islam for each crime there is a punishment set in advance and nobody could be punished for the crimes that others committed.

As a matter of fact, the few above mentioned issues are only the examples of the traditional practices applied on women which are contrary to Islamic values and in fact all the traditional practices and every other action which is violating women rights are against Islamic rules and Muslims have been instructed to 


\section{Impact of traditional practices on women}

avoid such actions. In the coming pages we will review more of such practices with more details.

Consequently, although it has been more than 1500 years that Islam have been introduced to the world and over these period of time many changes have appeared in the world but none of these changes are out of the forecast of Quran. So. if we act up on the guidance of Quran there will be no tradition and no act which could violate women rights.

\section{Human Rights and Traditions:}

The Human rights is the set of the norms and principles which bind all nations of the world morally and ask them to respect certain rules and principles. In different periods of time the nations of the world tried to bring peace and justice to the world in many different ways, the Universal declaration of Human rights adopted in the year 1948 was one of the examples of such efforts, binding all nations equally with its norms. The declaration itself could not guarantee the human rights with all means, so in order to bring more strength to the human rights application and to strengthen the commitment and accountability of the

nations to human rights principles every year many other conventions and protocols are introduced and countries are encouraged to respect it and to bind themselves to that, through which the countries are encouraged to fortify their local and national laws according to the mentioned principles. Meanwhile these conventions and protocols ask the countries to report on their performance to the United Nation in regular terms and periods. In addition to the general guidelines and documents in regard of strengthening human rights, with reference to the need of vulnerable groups like children, IDPs, Refugees, women.... Special 


\section{Impact of traditional practices on women}

procedures and arrangements are made by $\mathrm{UN}$ as well, this way the efforts are made to bring more justice and guarantee the equal right of every body.

Meanwhile. the high commissionaire for human rights in many different topics and issues which have a link to issues related to the human right for a particular category or in a particular place appoints its special representatives to report on the situation and to reinforce the effort to increase the respect for human rights. This way the UN tries to avoid violation to any category of the human beings and also if a place or a particular group of people in the world are suffering from a problem or an injustice the UN tries to put the efforts together and encourages other countries to step in and help to overcome the problem. If we think of such actions taken world wide we can clearly see that none of them are obligatory rules but traditions which link the countries morally and have been practiced for a long period of time. The same principle and tradition could be applied within a country as well, as in Afghanistan we also have lots of such practices which turn to be common and in fact they are very much positive. As an example we can name Loya Jirgà (grant council), respecting and helping each other in a neighborhood ... which is not contrary to the human rights principles.

Meanwhile, although Afghanistan is a member of the UN and also is party to many of the declarations. protocols and conventions, which obligate the countries to respect and apply certain human rights principles, but still we are facing many problems and injustice towards practicing human rights and mainly most of the traditional practices applied on women and children are in contrary with Human rights principles.

As mentioned above, in Afghanistan women are considered as one of the vulnerable groups which needs special attention and this is way many of the 


\section{Impact of traditional practices on women}

traditional practices identified as opposite to Human Rights are in relation to Women and it affects their life very adversely.

During the discussions in the conference the participants named a number of traditional practices which violates the right of women, and as the practices become so wide and usual even the women themselves believe in the normality of such practices in their life.

Bellow you will read the examples of traditional practices which are clearly contradicted with human rights of women:

As when a baby girl is born in a family most of the time they feel sorry and get upset and meanwhile if it is a baby boy his birth is hugely celebrated.

The discrimination among boys and girls are not limited to that but it starts from this stage and it continues over her life time and covers all aspects of her life from education, to social relations, marriage, economy, etc.

\section{Access to Education:}

Based on different studies the rate of illiteracy is very high among Afghan people and when it comes to women it is even worse and one of the main reasons being is the discrimination pointed out above. Based on such discriminations, the families are less willing to send their daughters to school, and even if they want to send them, they have limited resources and opportunities. They prefer to send sons than daughters, which is strongly contradicted to the Convention on the Rights of the Child (CRC) article 2nd. 


\section{Impact of traditional practices on women}

\section{Forced marriages:}

The CRC defines any person bellow 18th as a child, and considers them as immature. This fact affects all affairs of the life of human being including marriage, but the traditional thinking and the mentality of the people in many of the incidents lead to the marriage of people under 18 th and even as young as 10 to 7 years old, applied predominantly on girls. More over, when it comes to marriage women and girls do not have the right to express their views or involved in the decisions and they should obey the decisions taken by family especially male member of the family.

\section{Words, phrases and proverbs used for women:}

Using names and words are very important when it comes to the mental and moral growth of the people from the childhood, as we know it is very common that women and girls are named and called with many different words in the families which become very natural; which from a psychological point of view disturb them mentally and affect their growth:

Neek Sar: when a baby boy is born after a girl this girl called Neek Sar (Good person)

Bad Sar: If a baby girl born after a girl the first girl called Bad Sar (Bad person)

Sia Sar: girls from their birth till death called Sia Sar (black headed)

Aajeza: women are also called Aajeza (as disabled and bad luck person)

Calling women from very early ages with the above mentioned names and many more of these types affect them psychologically. From the very early age they 


\section{Impact of traditional practices on women}

believe that their birth and their existence is a matter to be sorry for, so they grow with a guilty feeling from the beginning and this feeling transfers from one generation to the next and slowly it becomes a natural reality of their life.

Also some of the examples of the proverbs in this regard were mentioned by the participants of the conference:

- You should kill the cat when she steps in (women should be under control and pressure from the first day of the marriage)

- don't consult with the women as they are not mature mentally

- hide your important issues from your wife

- Women is Obey

- Zan Bezan, Agar Murd Degar Zan Agar Namurd Degar Zan, (women should be beaten, if she dies get second wife if she doesn't, beat her again.)

\section{Mentality exists regarding women position in the Family:}

Based on the traditional believes among the families women in the family circle is considered as secondary human being, in most of such families men are in the high rocky of the family tree and he is the one who can decide about every thing and his word is final word. The women have the second role after all men in the family. The wife should consult and ask for permission from her husband and in the absence of the husband from his brother in law, father in law ... in different ways if she wants to do any thing, regardless of their age (if she is not married she has take permission from her father, brother...) 


\section{Impact of traditional practices on women}

As one of the participants of the conference explains an example about it:

As I was working for a health education program we needed to hire some female health educators, so I went to one of the families which I knew there are women who can work with us and as her husband was not in town she said although her husbands would have been agreed if he was there but because he is not there she has to ask from her brother in law and when she asked, he refused so we needed to wait for her husband or should convince the brother in law, and it took plenty of time for me to convince him and only then she was able to work with us.

\section{Legislation and traditions:}

In the legal system of our country the traditions are accepted as the main source for the legislation, but when we talk about the traditions as the source of legislation. we talk about the set of traditions which are in conformity with Islam and human rights declarations and the traditions which are not against mentioned principles. Also the cause for having legislation and written law as mentioned in its historical background is mainly to avoid any irresponsible actions by the people in power and to make every body accountable before law and principles and the important element of any law in the world (including Afghanistan) and it should not be in contrary with religious and human rights values.

But what is important and this report tries to emphasis is the circle for the implementation of laws and rules, unfortunately the executive aspect of the rules and regulation have been very weak over the years of war and even before and after war period (till now). Main reasons for the lack of applications of the laws in the country's present life is the lack of professionals and law enforcement mechanisms and structures all over the country, high rate of illiteracy among 


\section{Impact of traditional practices on women}

people, the main factors for turning of people in many parts of the country to practice traditional norms and rules. Since these traditional norms are not written any where and the main source for generating such rules are not clear so it applies from the people of power to the rest of the people who are mainly vulnerable.

At the same time, if we pay attention to this issue from a different angle we also can say that the written laws of our country, because of the years of war and the brain drain of the people is not responsive to the needs of the today's life of the country and in many parts it needs to be rewritten and reformed, as for many of the current violence in the today's society are not very well addressed by law or its reference is very weak which can not ensure the equal right of every body.

More over because women have less presence in the public and their access to education and social life is limited they are not aware of the rights given to them by laws, and that is why they are the main victims of the violence caused by traditional practices, and because they don't have access to the law enforcement mechanisms no body tries to ensure justice for them.

Fro among the practice applied on women which is in contrary with Legislation enforced in the country, we can name forced marriages, early marriages, physical abuse... which is very common. So there is a strong need for reviewing the existing legislation of the country in order to bring appropriate and positive changes about, which can bind every body with its rules and regulations.

To make it short, the other main problem occurred when we are talking of Legislation and tradition is creating and improving the sense of escaping from the laws by the people and when people get used to traditional practices then it 


\section{Impact of traditional practices on women}

becomes more difficult to apply rules and also we should take this issue in to consideration that only by changing rules and improving legislation we will not be able to reduce the violations to the women rights; we need to bring more awareness and moral strength to community and increase the sense of respect to rule of law among people.

\section{Governance and Traditions:}

Since the fall of Taliban, the Afghan Government always mentioned the issue of war lords, local commanders, drugs and many other issues as main problem towards peace and justice for Afghanistan but failed to mention the tradition practices as one of the main challenges towards development and women rights, which is even greater and more serious than many other problems. Because the existence of practices mentioned above can create social unbalance and can lead to social disasters in the country, can create obstacles towards enjoying the normal and natural rights to different groups of the community.

When we want to move towards peace and justice the issue of traditional practices can be seen as one of the main problems and obstacles in this regard, which we need to struggle against it even before any other issues. As above we mentioned the issue of legislation and traditional practices and pointed out the problems in regard to that now we should mention that the reason for the lack of application of the legislation is the weak performance of government structure. The law enforcement structures like police, public prosecutors and other related departments play a key role for implementation of rule of law.

Meanwhile we should mention that the strong believe and linkage of people to local norms and their own made structures could be seen as a treat to 


\section{Impact of traditional practices on women}

Government, because by the time these structures get strong people in such places are unlikely to see themselves part of the country and it is unlikely that they would obey national rules in a longer perspective, as in a traditional and tribal community all faiths are based on language and tribal divisions and interests, for examples in Afghanistan today if some one is in the position of power they tries to place as many people of their groups and tribes as possible.

In the same way when a traditional practice violates the rights of women it creates many different applications and it shows that the government have been failed to fulfill one of its important duty of "protecting the rights of the citizens".

So bringing the judicial reform itself will not be enough to resolve the problems created by traditional practices, to do so, government needs to adopt different long term and short term policies for raising the awareness among people (on the contradiction of such practices with Islam, Human rights and rule of law), strengthening the mechanisms of law enforcement country wide, building the capacity of judicial sector and many more.

As movements from darkness to brightness needs to be slow down and otherwise it could create problems for your eyes in the same way our movements for such struggle also needs to be slow and step by step and according to the understanding and capacity present in the community.

\section{Justice and Traditions:}

The judicial sector is one of the strong elements of a governmental structure in each country including Afghanistan, but in Muslim countries Islam has also given special power to this structure, this is why the constitution of Afghanistan also recognized it as the special power of this structure. 


\section{Impact of traditional practices on women}

In fact the only way to apply rule of law and ensure justice in a country is to have a strong, independent and professional judiciary, as they are responsible to ensure social justice in the country ( this issue is more evident in the swearing statement of each judge while taking over a judiciary post). In short the constitution gives a very strong responsibility to the judiciary of the country, which is in need of having appropriate and strong structure and facilities as well.

As was explained above the main problem towards applying rule of law and ensure justice is the existence of traditional practices and traditional structures which act as informal justice system in the country, and as the formal judicial structures and personnel do not exist every where in the country, so these structures become more strong day to day. In addition, while people don't have any other means to solve their problem in their area so they refer to informal justice system as a result of which the level of trust to formal justice is reduced gradually.

Bellow we want to refer to the issues within the judiciary which lead to the strengthening of the informal justice and it need a special attention:

1. It has been noticed that the judiciary personnel in some parts of the country are the head of the local councils as well, under the current mentality of the public they are also the applicators of traditional norms,

2. The lack of the judiciary structure and courts all over the country also contribute to the fact that the informal justice becomes stronger and replace the judiciary and lack of transportation means make people to refer to informal structure, 


\section{Impact of traditional practices on women}

3. Low level of public awareness from the laws and procedures in provinces, districts and villages also have a strong contribution to the wide practice of informal justice and when it comes to women this issue becomes stronger than usual.

4. In the case of women another contributing factor is the limited access to public life. It is unlikely even if they know their rights to ask for justice or refer to any judiciary structure,

As a result, we should keep in mind that considering the above mentioned issues lightly or not paying attention to such an important and crucial issue will cause to strengthening of the informal justice system which will damage the justice value in total. 


\section{Second Section}

\section{Traditional practices in Afghanistan and its impact to the Women Rights}

Our traditional society is overvalued by traditional practices, which mainly affect women life and most of the time violate their rights. In this part of the report is the summary of the discussions during the conference regarding identifying traditional practices, analyzing its direct impacts, seeking solutions and also identifying structures and organization which can contribute to reforming the situation in this regards:

Most Common Traditional practices applied on women:

As was mentioned before, although we have number of positive traditional norms but here we would like to name the practices which violates the rights of women in different parts of the country and will also try to analyze some of these practices:

\section{A. List of traditional practices regarding women:}

1. Bad

2. Forced Marriages

3. Toyana (Bride Price) 


\section{Impact of traditional practices on women}

4. Multi marriages (against Islamic instructions)

5. Exchange of brides between families

6. Early marriages (age difference)

7. Giving women in compensation of debts.

8. Forced marriage of widows to the relatives of husband

9. Avoid paying the heritage shared with women

10. Engage baby girls when they are born to be married to some body later in the life,

11. Discrimination against women

12. Not permitting girls to access to education

13. Exchange of women with animals

14. Exchange of women with drugs

15. Absence of women in the decision making process in the family

16. Avoid women access to social work and employment

17. Avoid presence of women in the local councils

18. Lack of economical independence of women

19. Feeling ashamed for the birth of girls and feeling proud for the birth of boys 


\section{Impact of traditional practices on women}

\section{b. Analyzing the most common traditional practices on women:}

Although all participants of the conference were agreed that there are more damaging traditional practices existing against women, they emphasized on a number of most common practices, bellow you will find a brief description of each discussed tradition:

\section{Childhood Engagements (early marriage):}

One of the most common practices in Afghanistan is the early engagement of the children, the way these traditions are applied might be different in various parts of the country, but it has equal implication. This tradition is mainly applied by families of boy and girl, and mostly the main cause is the poverty (of the girl's family) and power (of the boy's family) but sometimes it also happened among families who are relatives to each other or friends and they are happy to build a new relationship. The implication of this tradition is negative in most of the times and when both sides are mature this family decision turn to forced marriage.

The way this tradition is applied is; when a new baby girl is born in a family, some time the family who have a baby boy comes and for the baby girl (in some part of the country the mother of the boy came and sweep the door step of the girl house and it means that they ask for the girl) and in some other time the issue of power is involved and the boy family which is mostly older than normal; shot from a gun and by this means announce that this new baby girl belongs to his family from now on so nobody including the girl's family cannot dare to refuse. 


\section{Impact of traditional practices on women}

\section{Forced Marriages:}

This issue is also very much common in different parts of the country, even among the very civilized families it looks like a very natural issue. Although forced marriages are mainly applied on women but in some cases men are also the victim of forced marriages. Some times families are the main actor in applying forced marriages but as was mentioned before mainly the position of power whether economical, political, military or social influences could be counted as the main causes for such actions.

Based on the Islamic norms, consent to marriage is the crucial elements of marriage, without which the legality of the marriage is under question. but as the Islamic knowledge has been weak among the public, most of the time to marriages are arranged by putting pressure to the women and is totally based on tradition, which has very damaging application to the life of the young couple. It really happened that the forced marriage is successful, because in the forced marriage both sides can not make their own decisions, their choice and thinking is not involved in the decision, which cause lack of interest to the marriage life, psychological problems, wrong impact on children, and even in the worst cases it ends up with suicides and mental illness.

So raising awareness of the public and families to the side effect of such actions through religious leaders, teachers, and other well known people in the public is very much crucial, meanwhile government should encourage marriage registration and formal marriages so it can reduce the problem in this regard. 


\section{Impact of traditional practices on women}

\section{Considering widows as property of husband family:}

In most parts of the country it is quite common that the widows are considered as the property of the husband family. By the time the husband dies immediately the wife loses all her power and rights, and she is not anymore considered as an independent person. In most of the cases the way of her life is chosen by the inlaws, even the in-laws are able to remarry her to one of their sons or any body at all in their family regardless of her agreement, age difference. positions, etc. If she refuses, then she has to pay a very high price for that and it means they will take away her children and make her to leave the family inmmediately.

The decision in this regard is mostly taken by the in-laws, and the women could not interfere at all.

The impact of such marriage is obvious as it was in forced marriages (this sentence to be inserted in Dari version as well)

To overcome such practices again there is a strong need for awareness raising among public, building the self esteem of women, helping them to become economically empowered, advices from religious leaders... could bring a positive change to the situation. Meanwhile strengthening the rule of law, easy access of women to justice are the most important elements of ensuring women safety in this regard.

\section{Exchanging women:}

The main cause for such tradition which is very much common as well is the poverty and the families for reducing the heavy cost of marriage ceremonies, 
agrees to exchange their daughters and reduce the cost and arrange both marriages at the same time.

If you look at the issue at first you won't find any problem with that and you might think what is wrong with that, but a deep analyses and looking to the situation of couples who married in the above mentioned condition make it clear that it has damaging impact to the life of them. (to be inserted in Dari version as well) as the life of these couples are joined now for ever with each other and every and each up and down of the life of one couple effect the other as well.

As we read in the following example:

In a family the two couples were married in the above mentioned way and in one of the families the situation gone worse and the problems between husband and wife lead them to divorce. but the second couple didn't have any problem. By the time the divorced women came back to her father house her brother ( 2 nd couple) divorced her wife too, so in this way both families got in to trouble.

The above mentioned example clearly shows the damaging effect of such practices in the families.

\section{Avoid payment of heritage to women:}

Access to the heritage is one the rights which have been given to Muslims mainly by Islamic rules, but in practice this rights has been denied to women in most of the cases and their claim to receive their heritage will face to aggressive behavior from the brother, father and even mother and it creates many problems in their family relations. This is why some time women them selves refuse to 


\section{Impact of traditional practices on women}

receive their share to avoid conflict in the family but most of the time if the claim still they will not receive any thing.

The main cause here is the strong decision making position of men in the family and also the mentality that women don't need wealth, because they are the responsibility of men (father, brother, husband, son...).

But we should think of the women who are divorced or simply don't have any male accompany but still they need to survive, there are women who lost every body and they haven't had any chance to work and gain income, but they need to survive and there are women that the share of heritage could save their life with their children life. Still these traditions denying this right from women, which could be one the reasons for women's weak economical power. The consequences brought up by such tradition is facing women with economical problem. which lead then to forced marriages, suicides. self immolations. moral crimes and so on.

\section{Bad:}

This tradition have been applied mainly by local councils and traditional informal justice systems, which involves religious leaders. economically powered people, influential people, local commanders, etc in the decisions.

The traditions applied in a way that to reduce the conflict among families which caused by killing. robbery, loan, running away, rape... a women from the abuser family is given to victim family as exchange of the damage. Basically the justification is that such tradition will reduce the conflict and by creating family relationship the abuse will be forgotten, but in reality and based on in depth researches have been done and the practical examples given by participants this 


\section{Impact of traditional practices on women}

action will never put an end to the tension between two families but will increase it and more over another innocent person (the women) has to sacrifice for the crime that others have committed.

\section{Multiple marriages:}

Although Islam has granted the right for more than one marriage to men. but meanwhile has made it conditional to very difficult and almost impossible prerequisites, and the reason being is that except for unusual situations nobody can just marry for several times just for fun or for sexual purpose. But unfortunately what has been practiced in Afghanistan today in regards of polygamy (multiple marriages) is not based on Islam and it is only based on traditions. Who can imagine that the number of the multiple marriages in Afghanistan is even more than any other country in the world. and maybe out of each 10 women in Afghanistan one have been faced or have the fear of facing such thing in her marriage life.

But what men justifies mainly when they are marrying for more than one time is not having sons, and because they think that sons will help them when they are old they make such decisions but most of the time even in the 2 nd. 3rd ... marriages the failed to have sons. Nevertheless, according to the participants. the main reason behind these polygamies is nothing but their whishes. desires and wealth which makes them to marry several times. which never could be justified based on Islam and the rule of law.

What is more painful is that most of the time it is women (mother. sister...) are perusing the men to marry for the second time. meanwhile as mentioned. the civil law has pointed out some guidance and instructions as of article 84 but the 


\section{Impact of traditional practices on women}

law enforcement mechanism has never taken this issue seriously. It launches conditions but never says that if such thing happened against law what the punishment would be.

Meanwhile because this tradition has become so wide spread slowly it turn to be a very naturally to have more than one wife, while the impact and the consequences brought up by this tradition will never be a natural thing and it is very much damaging. from such damaging impacts we can name the conflict over heritage, discrimination among children, and wives, etc.

One of the main cause for the women to obey the action of her husband for second time marriage is because they are economically dependent to their husbands and in case of resistance they have no option. no place to leave; and she has to accept it as her destiny.

Meanwhile she has the fear that if she wants to live separately from her husband or ask for divorce so then based on law she will not be able to have her children.

In the opinion of the participants of the conference the main solution to overcome such problem is to reinforce the rule of law, and strongly implement it; because if the law is applied on women for not receiving their children but the same law which provides conditions for the second marriage of men are never applied, so if we want to resolve such problems we ought to improve our judiciary system.

\section{Exchange of women with animals, drugs, debts...:}

This tradition is one of the most unfortunate practices in our country, but it is mainly brought up by years of war, and when you want to categorize it, we can put it as a variety of BAD practice (which was mentioned above) but as this 


\section{Impact of traditional practices on women}

tradition is more disturbing the participants emphasized to address it separately as well.

Based on this tradition for different unjustifiable reasons and based on the decisions made by local councils and some times families, it applies again on women and the exchange to receive animals, drugs, pay debts, receive lands, etc, which without any doubt is less worthy than the life of a human being.

The underlying factor for such an unfortunate action is ignorance, men's weak conscience, poverty... which have brought many different examples.

Please read bellow some examples about this mal-practice:

A men was arranging the marriage ceremony for his son and based on traditions when the bride has stepped in to her husband family the in-laws should kill an animal like; chicken, goat, sheep, cow to welcome her; and as this men didn't have money to arrange for it; he gives one of his daughters to a land lord in the village to receive a cow.

Also in another example:

A men had the Buz Kashi hobby (a traditional game in Afghanistan which plays by horse and also a dead goat) and during a match his horse was sick and he was about to miss the match; so he gives one of his daughters to exchange it with a horse.

\section{Not permitting girls to access to education}

One of the main problems in our society is the lack of access of women and girls to education, which is the cause for most of other social problem and is applied 


\section{Impact of traditional practices on women}

based on the family decisions and sometimes other reasons like; security, limited facilities. etc.

The decision to avoid the access of education for girls is totally against Islam and mainly the first guidance brought up to prophet Muhammad (PBUH) which was saying (Eqraa....) it means read, in an imperative accent.

Although today people and families slowly come to understand and realize the importance of education in their life but still in most parts of the country if a girl is going to school even in a very primary level considers a big shame for the honor of the family. And even if a girl is lucky enough to get the chance to go to school by the time somebody asks the family to marry their daughter, she is immediately taken out of school; and the next day poor girl instead of going to school has to go to the husband family and survive there for all of her life.

The damaging impact of such action has caused the isolation of women from the society and most of the time they commit suicide. self burning. running away from the house and many other actions.

\section{Expensive Marriages:}

Marriage as the beginning of a new life. is one of the important events of ones life in our country and based on traditions, people want to celebrate it as luxurious as possible, which is considered as fun time but at the same time the illogical, unaffordable provide some joy for some families but for most of

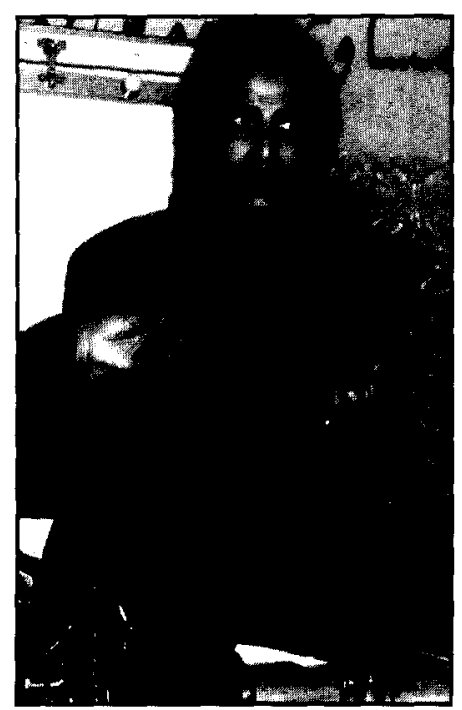




\section{Impact of traditional practices on women}

the families it is very much damaging and even it

Causes immediate divorces and difficult living conditions for a great part of the young couples. As for having a very luxurious wedding party, they have to arrange for big amount of money and some times if they don't have such amount, they have to take loan from others which then after marriage they need to spend all the time and energy to pay the loans.

Although some times arranging for luxurious weddings are voluntary but most of the time it is compulsory and by force which then will have many negative implications. If the bride family forces the groom family to pay high price for the marriage (in Afghanistan wedding ceremony organized by groom family) then after marriage the position and the personality of the new bride is not very good in her in-laws family and also it provokes violence, fighting ... among the family.

Also if we want to look at this issue from another angle, we might realize that this traditions obligate young men who do not have enough wealth to arrange for such expensive weddings and pay the high marriage cost, they remain single for longtime and meanwhile because this is the families who applies such traditions many of the young girls also will never have the chance to marry the person of their choice. Creation of such difficult conditions for the young people who want to get married and start their new life some times lead to elopes, moral crimes, psychological problem...

\section{Physical abuses:}

Applying physical abuses on women and girls are one the very common practice in almost every family, as men have more physical power; they are willing to use 


\section{Impact of traditional practices on women}

their power against the women if women do not obey their orders. This action does not only cause physical suffering and disturbance but also creates many more damaging impacts. psychological problems, committing crimes against the abusers. suicides. moral crimes. etc from the women part.

\section{Decision making structures and their operation mechanism:}

As was mentioned before, the traditional practices could be applied by different structures and even individuals. These traditional structures might differ from each other on their historical age and also the way of operation but all the decisions taken by all these structures are compulsory and the villagers, the family members or any body else who is living under one of these structures are obliged to obey; otherwise sets of punishments are set out by the structure like separation from the family, taking him/ her out of the family or structure and sometimes more hard reaction.

Bellow we will review some of such structures which was mentioned by the participants of the conference as the main structures:

\section{Jirgas:}

One of the well known traditional structures for decision making is the Jirga, which is popular for settlement of disputes all over country and is consisted of local influential community members.

A. the structure: the members of the Jirga is mainly elderly people ( also referred as white-bearded men) which are called Mesher. All members of the Jirga have equal rights in decision making and now we name each of these members: 


\section{Impact of traditional practices on women}

- White-bearded: respecting the elder people (white-bearded) is the responsibility of all members of the society ( people get punished if they don't respect their elders ) and normally they are known for their experience a fruit of their life.

- Khan (land lord): he is a member of Jirga without question because he has wealth and pays the cost of many different religious and local events and is respected by the community and has special power. Khan is the member of the Jirga but sometimes he is the one who calls for convening the meeting. he also manages the village.

- $\quad$ Religious leaders (white-turbaned): they are also very much respected in the community and are playing a crucial role in reducing and solving conflict as they are well known for their Islamic knowledge. Historically during wars these are the people who put white turbans and by getting the oat of both side of depute on Holy book of Muslims (Quran) they could settle a dispute.

- Village leader (Sar Khail): this position is common in tribal life and each tribe has a leader and they are mainly KOCHIS (nomads).

- Malik: also is a position of power in the villages and is the member of the Jirga.

B. Method of operation: the procedure of operation is that the members of the Jirga come together in a open space or most of the time in the mosque and after discussing the issues make their decisions. Nobody can refuse the decisions and it is compulsory: they disobedient receive punishment which will be applied by a group called (monitoring group). The Monitoring group is consisted of 10 young 


\section{Impact of traditional practices on women}

people and they are also called "Arbaki" in some places and they have a leader which they chosen from them by themselves. This group act as law enforcement staff and following up of the decisions taken by Jirga is their responsibility.

\section{Maraka:}

Maraka is a different type of the local structure and its difference with Jirga is that it is mainly held for minor issues and it has limited members.

A. Structure: following you can find the potential members in each Marak:

a. Marakchi (the members of the Maraka): these are the group who do the hearing of the cases.

b. Nekhyan (knowledgeable people): it calls to the people who have enough knowledge to solve problems, they are also member of the Maraka and they make decisions based on the rules and principles of the village (the principles are called Nerkh) the Nerkhi is not nessocery to be wealthy but is important to know the rules and principles of the village.

B. Procedure: the same as the Jirga. Obeying the decisions of this structure is also compulsory to the both parties.

\section{The Families:}

Families are also the main implementers of the traditional practices in the family circle but they don't have structure and procedures like Maraka and Jirga. But in the following issues families are the only implementers of the practices on women: 


\section{Impact of traditional practices on women}

\begin{tabular}{|c|c|c|}
\hline No & Type of tradition & Implementers in the Family \\
\hline 1 & Forced marriages & $\begin{array}{l}\text { Father, Grant father, Mother, grand } \\
\text { mother, brother, uncles... }\end{array}$ \\
\hline 2 & Denied access to education & Father, Mother \\
\hline 3 & Multiple marriages & Husband and in-laws \\
\hline 4 & Denied from heritages & $\begin{array}{l}\text { Brother, uncle, elder of the family } \\
\text { and some time mother }\end{array}$ \\
\hline 5 & Early marriages & $\begin{array}{l}\text { Mother, father, grand mother and } \\
\text { father, uncles }\end{array}$ \\
\hline 6 & Expensive wedding costs & Bride family \\
\hline 7 & Exchange of women by women & Families of bride and groom \\
\hline 8 & Exchange for animals, drugs.. & Father, brother, husbands.. \\
\hline
\end{tabular}

\section{Proposed solutions:}

Based on the three-day discussion among the participants of the conference the participants emphasized on the following issues as the main solutions to solve the problem in regards of traditional practices

As the main reason for applying the mentioned practices was identified the ignorance among community, so raising the public awareness and providing civic education to public including men and women is very much crucial which should be applied together from the government, civil society groups, religious leader..

Expanding and strengthening the rule of law is another important element for elimination of such harsh practices from afghan women's lives. 
Meanwhile actions like improving security, equal access to education, providing chances to increase income generation opportunity for the families and mainly for women could contribute strongly as solutions. (Detailed proposals for solution is highlighted in the conference declaration as annex 2) 


\section{Impact of traditional practices on women}

\section{Annexes}

\section{Speeches:}

\subsection{Dr. Suraya Subhrang Duputy Minister of MoWA}

\section{Topic: Struggle on violence against women:}

With greetings to every body and thanks from WCLRF for

Organizing such conference;

It is too difficult to speak in a among very knowledge-

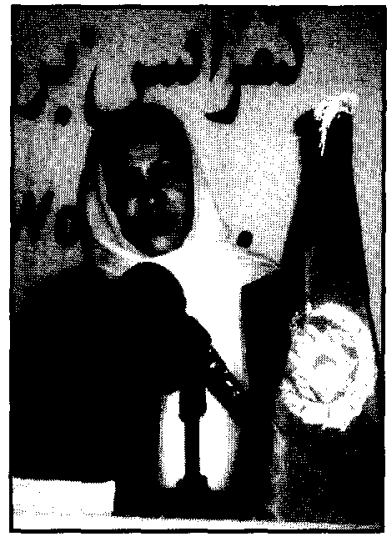

-able personalities but as the issue is important I want to raise some points: Seeing that every body knows we are living in a society, where traditions as unwritten laws are stronger than rule of law applied by government of Afghanistan. I think we should review analyses of the practices to see what the good and bad practices are in this regard. It is a reality that we have a number of practices which are part of our honor and are cultural heritage of our country and each of us has the responsibility to make and keep these traditions alive and transfer it to the next generations. These traditions are like tolerance, helping each other, consultation... but besides that unfortunately we have a number of bad practices as well which applies mainly on women and these are the main obstacles when we are trying to analyze the situation of women in afghan society.

Regarding the position of the men and women in the society we can bring the old example of the two wings of a bird. as women and men considered like the two wings of one bird, which with out one of these wings the bird can not fly; the 


\section{Impact of traditional practices on women}

same is the movement of the society. In our society one wing of the bird have been tied up for a long period of time and although now there are a number of opportunities still this wing of the society can not fly properly; why???

One of the main causes is the customary law in Afghanistan, which creates an environment of conflict and violence for women and in such situation these are men who rule the family and the society and the women are to obey such rules. So one of the main points for tiding up of one wing of the society is traditional practices; as one of the knowledgeable persons says: (the situation of women in a society is like the mirror which reflects the level of civilization in a society) from this mirror you can judge and measure that how much this society is advanced. so if in a society half of its population are ignored and their role has been denied in the political, economical and social affairs; such a society will not meet the criteria of a civilized country or society.

If we consider traditional practices as one of the main causes of violence towards women. we clearly see that such traditions originates from the grassroots (from the birth of the child) when a baby girl is born in a family the reaction of the family towards the event is different than if it was a baby boy; and for the girl every body gets upset and feel sorry for not being a baby boy. It means the traditional discrimination against women starts from her birth and then it gets further in the issue of going to school, as the preference is that boys should go to school if the facilities are limited or simply because girls don't have the permission in most of the family to go to school. So this is the cause that now we have majority of our country (75\%) illiterate and among them rate of illiteracy of women raises up to the $92 \%$. 


\section{Impact of traditional practices on women}

So if we claim that women should have equal presence and participation in social, political and economical life it starts from equal opportunities in getting education and skills, while majority of women in our society have been denied to access their right to education and this action in itself is a kind of violation, which has a root in our traditional practices.

In the same ways when the age of a girl child is raised up to the 10 or 12 , immediately she should be married, and it is clear that in such an age she is not mature enough to take over the responsibility of married women and can manage the family. The tradition of early marriage beside its damaging impact on the family life also causes that the majority of women remain illiterate.

Also when we look at to the issue of health. if a woman is ill and she is not carried to hospital until her conditions gets worse and she is close to death, which also has a root in the traditional thinking of people, which thinks that taking women to a doctor, as she needs to get permission from her husband or if the husband is not there from her brother in law, father in law or any other male member of the family to go to doctor and if they say no so she can not go. (The doctors in villages are mainly men, as women have limit opportunity to become doctor and then work in remote area and villages). If we pay attention we can see that in every half an hour a pregnant women dies, which it self is a catastrophe and it is main root is in the traditions.

Meanwhile in the issue of economy, most of the women in our country are economically dependent to male member of the families, as they are mainly illiterate, and also based on traditions they are not allowed to have public presence, or learn skills or work anywhere. And their economical dependency causes that they have no any role in the decisions making at the family level and 


\section{Impact of traditional practices on women}

if the women are not economically strong they will never be able to claim their equal rights with the men, because if a women works it helps her a lot to maintain and strengthen her personality. So I think with finding solutions for such traditional practices we will be able to move forwards and ensure women rights.

And to overcome the traditional practices in our society, the society needs to bind with rule of law and through strengthening the rule of law we will be able to ensure justice and equality for women and stop violence.

We heard that, a husband some time ago cut the nose and ears of her wife and then put boiled oil on her, because she kissed her son in law. Do you think such an action could be justified by the name of culture; absolutely no, these are the hard traditions brought up by years of war to our country, and doers of such actions are mentally sick, as based on an assessment $70 \%$ of our society is mentally disturbed. Also what do you think of the incident in the Kabul University: when one student killed another student in the public, do you think he was normal, no, he was not. We should mention that most of the incidents we have witnessed in our country has nothing to do with our culture and it is only the culture of war and violence which slowly take over in the traditional practices. as unfortunately today we are facing cultural poverty, we have to fight against it for a long time, until we will be able to find the honor and privilege we had before.

We come back to the point of the need of improving the rule of law, as today we have the new constitution which, guarantee most of the rights for women and also as reference to prohibition of traditional practices. 


\section{Impact of traditional practices on women}

President Karzai in one of his speeches in the event of birthday of Prophet Mohammad (PBUH) referred to the traditional practices like. BAD. Exchange of women, early marriages as the practices against Islam and asked the religious leaders to fight against it and asked them to raise the awareness of people about these issues which are against Islam as there is no reference in Quran on that and also no where in Quran the women asked to stay at home and not take part in the social litè.

But we should note that to implement the rule of law and to ensure implementation of legal rights: women can play an important role and in fact their roles are much stronger than men. It means that women should not think or believe any more that knowing rules and making sure that these rules are implemented is only the job of men. the women should know and understand what is law and how it can help them changing their life. They should know what are the rights which have been guaranteed for them in the constitution, what is their civil rights... and when they understand all the above mentioned issues only then they will be able to seek justice and bring changes to their lives. then she will not feel as a week and feared person and then she will realize that laws have been given her particular rights.

Also it is important to raise the awareness among men on the issues related to gender, that is why we in the MoWA are trying to reach men as much as possible on this issue and train them on this important issue. then they will be able to respect each others right.

Also when we say that the laws should be implemented. it is important that at the first stage the way should be paved for this purpose, if the society is not prepare to accept changes it is impossible to bring changes: so if the society is not ready 


\section{Impact of traditional practices on women}

to respect and implement the rule of law it means that we have failed in implementing the rule of law as well. Consequently, when the public and the society get ready to accept changes then it is the time that, people who are aware and understand the issue help others to understand it well, only then public will realize that practices like $\mathrm{BAD}$, early marriages... are wrong. Today unfortunately we force a 10 years old girl to marry a 50 years old man; while these two belong to two different generations and never can suit each other and this is why we have an increasing number of suicide. self immolation and many other cases in which a women tries to end her life. That is why we believe that the impact of traditional practices damaging people mentally.

And when a mother (who is a women) has mental and psychological problem. how she could bring up mature and healthy children to the society, thus we will have a society full of social problems.

As we said one of the important elements for a national development program is to bolster the cultural side of the society. we should help our people to understand that BAD is bad. early marriage is wrong...

Although most of the people today don't have the patience and tolerance to accept that: Yes we have negative points and always we love to hear every body salying that we are perfect: but if we want to pave our way towards development. we should realize our weak points and we should change it to our strength and only then we will be able to aroid doing mistakes again. And to do so we need to put our steps slowly, we should not hurry up and should he very careful.

Thus we should also be happy that so far we have lots of achievements in insuring women rights, our new constitution with particular attention to women 


\section{Impact of traditional practices on women}

rights, the process of judicial reform. which we are very much hopeful for it and many other positive steps are all signs that there are improvements.

At the end, on be half of the MoWA, I would like to once more appreciate the initiative of WCLRF for organizing such an important gathering.

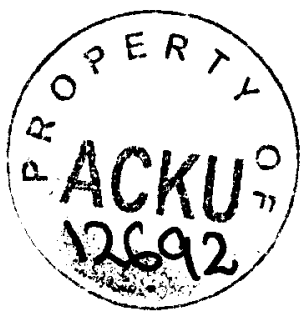




\section{Impact of traditional practices on women}

\subsection{Mr. Farid Hamidi, Commissioner at Afghan Independent Human Right Commission (AIHRC)}

\section{Topic: A glance on the traditional practices in Afghanistan}

I think that the title of the conference "the Impact

of traditional practice on Afghan Women" have

been chosen very much correctly and thoughtfully.

As by this way we will be able to address a part of

the social problems existing in our society which re-

-lates to our future social, cultural and political

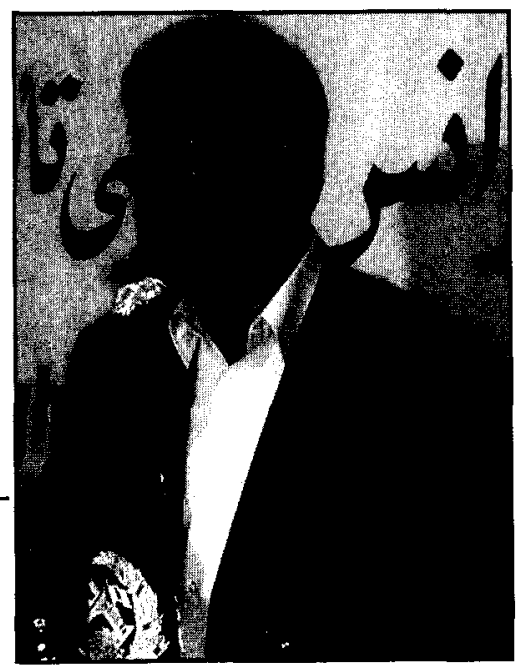

development and tries to build up a social balance. Because if we are not looking to our traditional practices and not distinguished among right and wrong traditional practices we will not be able to provide opportunities for political. social and economical development of our country.

In the past three years the Afghan Government has always addressed the issue of war lords. drugs... as main problems and obstacles towards development, but I think the problem created by traditional practices is even bigger, as it creates societal imbalance and bring obstacles towards development, democracy, social justice and also it stops people to enjoy their rights and freedom. 


\section{Impact of traditional practices on women}

That is why when we are moving towards development and carrying out the slogans of democracy and human rights. we should also try to bring changes towards our social behavior. One of the issues that has always been pointed out is that Afghanistan is moving from a traditional society to a more developed society. The traditional society is the society where faith and favor are not very deep. This is one of the most important problems in our society, because this issue creates lack of trust among people. which has its root in our traditional practices and believes. So we should understand that the problem with traditional practices is not only for women but is a problem for our nation.

Today if a person get an important position he/she tries to hire more her/his relatives and friends around and he/ she trust only the people who are close to him/her, as we have a very old proverb that "if a relative kill you he will pull your body from sun to shadow and if a noncreative kills you under the sun and will never pull your body from the heat of the sun out" this is why people rely more to their tribes. they think from a tribal perspective and it is the reason that national faith and favor is never get strong

The other problem brought up by traditional practices is the luck of public trust to rule of law and as a result of that escaping to implement laws; everyday we claim that if the there is no rule of law people will not live with peace but we never think of the reason for not respecting rule of and the reason is strong presence of traditional practices which slowly tries to replace the rule of law.

So one of the main problems towards rule of law, development, and democracy is the traditions, which we have to strongly fight against it. 


\section{Impact of traditional practices on women}

Before the issue of judicial reform was mentioned, but I think the judicial reform on its own will not be able to solve the problems created by traditional practices and the government should establish and implement many other long term policies to overcome traditional practices, and in this way we will be able to move towards democracy and rule of law and human right and ensures the access of people to their rights.

As was said we need to distinguish between negative and positive traditional practices. there are a number of habits which can lead us to peace and development and can give us our national identity, and we have to separate these from the shameful practices which decrease our honor and we need to get rid of them.

As we said there are number of good practices which now have become part of constitution, like Loya Jirga, the value of consultation, peace building..., which we have feel its impact over the period of time and luckily today it has been reflected in our constitution.

But strongly and urgently we need to fight against the traditional practices which are against laws, and principles of human rights, and we have to find different appropriate ways to overcome such traditions; and in this way we will be able to bring balance between democracy, rule of law and development in our country.

Today in Afghanistan we have so many different things and issues which are contradictory to each other and they are all practices at the same time; from one side we have traditional practices which create problems for our accountability towards Islam and rule of law and on the other hand we have principles and terms like Human rights, freedom, democracy.... And as all these different and 


\section{Impact of traditional practices on women}

various issues are living at the same time thus it creates an environment of conflict or the conflict of interest for us.

In order to ensure the political and social development of Afghanistan and bring the issues like social justice, democracy, people participation, human right and many more in to practice: we have to find and plant the seed of the issue in our society.

As I said before Afghanistan is a traditional country and if we want to move from such situation to a more civilized and mature society; a society where the legality of power. and structures are assured based on rule of law and justifications; we need to say good bye to traditional practices, traditional structures and thinking because most of these elements are the obstacles towards guaranteeing human rights in the country.

Also another issue; which is very much important is the traditional practices brought up by the man-lordism mentality and has damaging impact on the dignity of women and children and their life. Lets look at the traditional practice of BAD as an example: in this tradition we see that nobody can tolerate such an action that the crime is committed by a man and a women as to suffer or pay the price by going to the victim family and living their for ever; so thinking of such practice made as more strong in our fight against negative traditional practices. So fighting against such actions is not only important for defending women right but it is also crucial for building up social justice and bringing about social balance.

But. as her Excellency Deputy Minister has already stated; we need to slow down our efforts and think twice when we want to do any thing to confront 


\section{Impact of traditional practices on women}

traditional practices. and we should speed up in a way which can break and fail our efforts instead. So replacing the traditional structures and practices should be step by step and before that we have to prepare the mentality of public accordingly and these changes should not be in way which can create different negative feelings for the public: otherwise it will create another problem on its self

I hope this three-day conference can bring about practical and positive proposals for judicial reform and the expansion of the rule of law and by these proposal and suggestion we could go towards social. cultural. political development of our country. And I think our friends in this conference should keep in mind that; their proposals and suggestions should cover different aspects of our social life as we will not be able to over come with the problems of traditional practicing only by changing laws and we should go further and bring changes to our educational. political and cultural policies. At the end I will appreciate again the etforts of WCL.RF for organizing such conference. 


\section{Impact of traditional practices on women}

\subsection{Mr: lacel thmad Vanawi; Deputy (hief Justice; Supreme Court}

\section{Topic: Reaction of justice to traditional practices:}

I am very moch happs and proud of my

contriburion to the stregele lor somen

rights and I hate the honor that I am

also pare of the network on lighting for

"momen right: attongh I will not accept

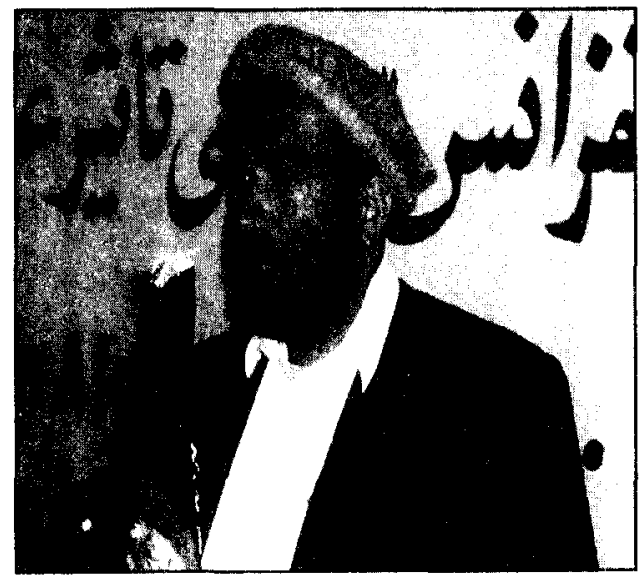

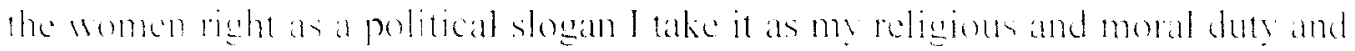
I helieve that esen it the sisters here are not tighting for there rights still we ats

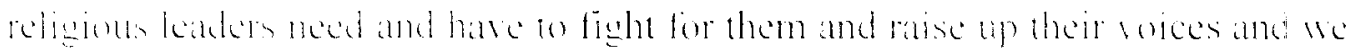

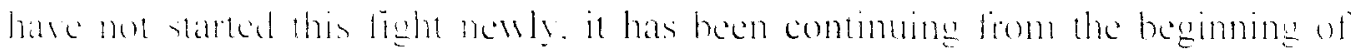
the lstam history: eren from the time of tirst human being (Adam) the violation of the rights was there and we know that still we have this problem and 10 will be continuing in the nex generations as well, but we have the duty to struggle

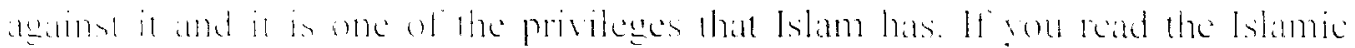
history sole can tind that one of the main objectices of Istam is ensuring women right: and hefore we raise our voices ahout: the (2uran in different verses has pointed ou the issue. and even we can say that the Quran is the beginner of the tight for women meht. It says in the Quran that in the day of justice (iod will ask the gerts that what was gour latult: ohe poor girls that you were punished. you

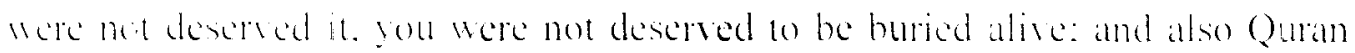




\section{Impact of traditional practices on women}

says that in the day of Justice (Qeamat) the abusers will be asked why they did so. in very hard way. We as Muslins believe that this world is not for ever and one day every body will pass on from the world and then we need to stand before God and face the God. So if we are performing wrong deeds by the name of religion, and we violate women rights using Islamic slogans we have to answer hefore God. And it is clear that all these wrong actions committed against women are just misusing Islam as it had happened in other religions too; if you see things done by the name of Jewish, it doesn't mean it has been written in their book, it is only their judgment and they way that people use the religious guidance. If people and countries doing things with the reference to their man made laws there is nothing to object but it is not fair to do wrong things under the name of religion.

So in short we can say that from one side there is nothing against women in Islam and in other hand Islam itself has fought for the right of women.

Every body knows the history of Islam; that when Islam came to Arab society based on its principles, the shame of having daughters had been lifted aside, and there were no more the problem of burying girl alive. Haziat Omar was one of the first Islamic leaders and we see that in his time he was famous for his justice and honesty, but even he had buried his little girl before coming to Islam. It has been said that Hazart Omar had a daughter but as having daughter was a matter of shame his wife didn't tell him about; when some body told him that "you are proud of heing an Arab Man but you have a daughter in your home, so how you can be proud of being an Arab" he came home and asked her wife about, her wife told him that yes it is true but now she is so quit and you can never kill her and she is now a growing up child. He asked her wife to call her. Omar says; when she came and I saw her she was really very beautiful and very quite but 1 


\section{Impact of traditional practices on women}

took her to the grave yard, and when I was digging the grave and the dust was covering my face, she was cleaning my face with her little hands, even all this nice behavior of the poor child didn't change my decision and I buried her alive in the grave. In most of the history books has been written that Omar was laughing some times and some times he was crying and when he was asked about: he was saying I laugh because I am thinking how stupid we were before coming to Islam and I cry because I fear that God will never forgive me for what I have done with my little child.

When Islam came it put an end to all these actions. so now you can see that the first struggle of Islam is to ensure women rights and revives their dignity and honor. Also prophet Muhammad was proud for having daughter and if you look at Islamic philosophy of this issue. you can see that Prophet Muhamad (PBUH) had no sons and all his sons were dead in the childhood and the one who brighten up her father life and the Prophet Muhammad was proud of her was Ms. Fatima the only daughter of Prophet Muhammad. May be it was a lesson from the God to Muslims that the only child of Prophet is a daughter; just put an end to the wrong ideology of Arab on shame for having daughters and not having a son for Prophet could not change any thing and her daughter is the proud and honor of Islamic history. But in our traditional society in Afghanistan like the ignorance period of Arab people violating women right, giving $\mathrm{BAD}$ is one the clear examples of thousands of such hard actions and practices; which we have to take this issue seriously to think about. Giving BAD is not the only malpractice. We have many more from a very small thing to bigger issues, as another example; when the officials went to villages while ago to register the population, they went to a family and asked how people are in your family; how many men and how many women? They got response; what is the name of 


\section{Impact of traditional practices on women}

women??? So in this point the Mullah (religious leader) of the village after pray told the villagers "the Government is not a Muslim government and the reason is they came and ask our wives names"; so you can see how the society is bound with traditional believes; that even the Mullah who is supposed to guide people can not differentiate between islamic and traditional thinking. But nobody can find any word in Islam which prohibit calling the women names as we know that the first Hadith in Islam is on the name of Ayesha (the wife of Prophet Muhammad), Fatima (daughter of Prophet Muhammad) and other women relatives of him.

In another example from my own life:

One day I had a very strong headache I did lots of medical treatment but it didn`t work so based on believe I went to Mullah to treat me, when I went their and ask for treatment, the Mullah kept quite and I said why he is quite, he said to my friend who was accompanying me, with very low voice, that "in order to do the treatment I need to know his mother's name, but I don't think it is good to ask her name". and even worse than that is that until my mother died I didn't know what her name was, and I just was familiar with her surname which she was called with, (as it is a tradition that no body should ask women's name), and when I linew that what beautiful name she had I put the same name to my daughter, as I want every body to know the name, and in fact it was a very beautiful name that she had.

Meanwhile when we are going to a marriage ceremony we see that it is too difficult to call the bride with her name and not even that when the bricle asked to give her consents to the marriage to two witnesses are coming from the mullah side he has to see her directly and openly and make sure that she is the one who 


\section{Impact of traditional practices on women}

gets married, but in practice they put a curtain in front of her and she has to confess very politely and with low voice that she appoint $\mathrm{X}$ person as her representative. And the reality is that even the bride doesn't need to appoint a representative and she could go and be present in the marriage meeting and announce her agreement openly. So it is the traditions that people now get them as Islamic principles and nobody dare to break such traditions.

This is why the prophet Muhammad (PBUH) in his last speech to Muslims (men and women who were present in his last speech) says "O! Muslims! Be scared from the God in relation to what you are doing with women." and the reason for this statement in his last advice which had many important advices to Muslims is that the Prophet knew that still there were violations in regard of women rights and still there were people who are against women.

So my suggestion to you all is one. you have to be very practical and careful of what you are doing to defend women which my self is also contributor to that. and I promised to many of the sisters that I will work with you and help to find solutions to the problems. As we are Muslims and believe that we have to be accountable to God for what we are doing. thus if we are not going to the right way and if we are doing wrong things we will be punished for that for this reason when we are trying to solve problems we need to think properly and find the best way for it. My second suggestion would be, that as I my self is believe to defend women rights and for that we should push for legal orders and solutions which can distinguish between right and wrong traditions. But it is not the only way to solve problems and to defend women rights and in fact it is the last solution. as an exanple if a woman have been given to BAD in a remote area of Badakhshan province, do you think only by punishing the doers according to law we will be able to solve her problem? No it is not the way, as we are 


\section{Impact of traditional practices on women}

punishing every day the numbers of criminals but the crimes are continuing. Thus I am saying it is the last option and solution and before that lets bring the trust among the public that giving BAD is wrong and it has damaging impacts; and this could be done through joint efforts of religious leaders, media, conducting workshops... and then if it didn't work we can use punishments.

Anyway today I left the meeting of the high council of religious leaders and came here and it shows how much we are committed to fight against women rights violations and this struggle should not be like our efforts to eliminate drugs and instead the drugs cultivation is increasing every day, we should not do things which can damage women life instead.

Thanks 


\section{Impact of traditional practices on women}

\subsection{Dr. Rangeen Dadfar Spanta, Political}

\section{Science Professor in German University and guest teacher in Kabul University}

\section{Topic: Traditional practices and society:}

Ladies and gentlemen, I am happy to have the

opportunity to talk to you in my beloved country.

As you know my profession is in political theory

and science from an international perspective and

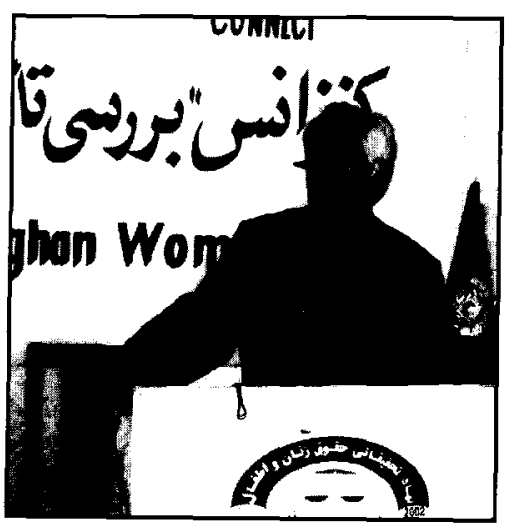

of course women rights and issues is part of the international relations I would forward few words but still forgive me if there were any mistake or shortcoming in my sayings.

What is clear that violation to women right has been continuing through out the history of human being, this is not only in Afghanistan and nor in Islamic countries, even in the most advanced European countries like Sweden and Norway, women don"t have equal rights and they can not find their place and position as equal human beings. Most of the violation in the most advanced countries applied on women and the women movements and women networks should fight against what is called obstacles to the moral principles in both west and east world. Because with out widespread struggles and without putting a question mark towards the traditional practices applied on women over centuries, access to equal right between men and women is not possible. 


\section{Impact of traditional practices on women}

Creating an environment of respect to democracy and governance building is not only able with the help of foreign countries; it is a process of social movement according to the national values and historical values of a country, and it is one of the points that women in our country should consider.

If we see the development on women rights from the first international conference on women right year 1975, we can realize that there has been improvements and women in different countries got access to some of their fundamental rights. for example in north Europe women have improvements in political. social and cultural affairs. Even they can not address the violence in the mind set of men and society.

Although their have been policies and programs undertaken by Governments in the last three decades in the area of education, capacity building, expansion of literacy: in the under development countries like Hindustan, and some of the Islamic countries still the rate of illiteracy is very high especially among women and to say it differently, women comprise the most illiterate, abused, and with minimum opportunities in the area of access to the education. But this is not the fault of a religion or religious believes, it is the fault of our social and political relationship which rooted from a position of power which in turn have its roots in traditional practices and believes; that exist very powerfully in our communities and it has to be changed.

When we are talking of violence we must remember that the violence has different types; the physical abuse and violence which men are famous for in the East and very commonly the use their physical power to abuse their wives and not only wives but all women in the family. That is why although the violence has a root in both East and West but the East is more visible in this regards. But 


\section{Impact of traditional practices on women}

still in Cicmany $32 \%$ of women are physically abused, this is a fact and figure that we might not believe, while many are talking about democracy and equality in these countries. In the university that I am working only $13 \%$ of the professors are women and the rest is men. and you see that the story which is telling every where is not true and the issue that violence is particular for Muslim countries and societies are not true. in fact women in other societies also don't have a better situation.

With all the improvements and changes happened in the world of technology and economy women are hopeful that their situation will also be improved but this rarely happened to become a reality. Because in a self sufficient society women are also engage in activities like gardenary, animal husbandry... and it helps them to earn income but with improving the systems and machinery like computers and etc which needs especial professionalism and most of the skills in this regard is with men, the movements from village to city is increasing and, the family economy becomes weak and as a result the women who had relatively fair economical situation before. with the reasons that they are illiterate and are not familiar with technology (this issue is common in Africa) they lose their economical value in the society and the face a double violence in their societies. and this system is applied on women even in the most advanced countries; as the women working hours are 16 when the working time for us in universities (the men) are 8 hours and even due when we go home everything should be ready for us. there should be tea and dinner and every thing ready.

In another different view the main contributing factor of violence against women in some of the societies like Hindustan (it is very common in Hindustan) is the lack of women access to education, skill building opportunities and proper food and the reason is that the girls and women are seen as a economical cost and lost 


\section{Impact of traditional practices on women}

for the family; that is why if you see the children in such societies you see that the boys have more healthy faces than girls. Because the food should be served first for boys and in this way the families are creating the environment of violence for their own children. When the girls and women are beaten and it becomes a routine action in the family then the violence becomes stronger and common in the society. And it is clear that a person whose rights have been violated can become the violators of others rights as well.

I remember that in our society when a child is admitted to school the first word from the mount of father to the teacher is that "sir; the meat of my child is yours and I only need the bones" (it means you can beat my child and punish him/her as much as you want). And I remember when my father told that I was scared too much and I remember that the first day when the teacher came told as "people call me Juma'ee Be Khuda" (it means a person who is strong and even not recognizing the God) and we small children were so scared. We went to the place that we should have been receiving love and kindness, but our first experience started with violence and abuse. And when a person starts its first experience with violence, then the violence becomes a very common issue for him/her and this violation will be extended from family to school, university and the society and such reality is very common and well known in traditional societies where there is no any value for asking the logic of any action and nobody ask that why, when, what; the circle of violation moves around and gets bigger every time and creates more violence. As when I started the university in the first day when the teacher entered the class around 200 mature and educated people (the students) stood up and we named it a tradition, meanwhile in the family traditional rules when a guest comes to your home every body need to stay awake until the guest is awake, even if the poor child has exam tomorrow 


\section{Impact of traditional practices on women}

and we call it tradition and if he/ she has exam tomorrow they have to stay till 10

- 11 o'clock at night with the uncle coming from a province and it is itself a structured violence and the continuation of such practices made it so common and part of our life. And because men are in a position of power and they believe that they are stronger than women; in most of the time they become the violator but the medical science has proven that women are stronger than men as they live longer than men and they face less incidents of heart attack and diabetes... and the only situation which women are facing problem more than men are headache and the normal death. So by this reasons the story of weak human being regarding women is not true and it is a man made story and that is the reason that women are thinking like men, dressing like them... it is as if you see the famous women in the world like Indera Gandi, and other powerful women they all tried to behave like men and tried to hidden their women nature, which is the main problem when we want to fortify the women as women. But with all what was said the violence against women has a strong root in the traditional practices. which is strongly present in our society.

There are different cultural patterns in different parts of the country and world, for example there are certain customs and traditions in south of Afghanistan that are not observed in north or in Kabul, and there are customs and traditions in north of the country, for example if you go to somebody's house in northern Afghanistan, the host brings food instead of tea, but in west of Heart host brings tea to the guests. But with all these customs and traditions there are some forms of violence against women, which preclude them form taking part in civil society. Even in the modern society, as I mentioned before, structural barriers exist that preclude women form having equal rights with men and it is much more intense in societies like ours. 


\section{Impact of traditional practices on women}

Let me mention some other problems too; one of which is women participation in national economic processes. If we possess a national economy, which we don't have right now, as the economy of the country is not nation wide yet, women are under dual pressure both in private and public sectors, i.e. they work both at home and outside home, and they don't have time for cultural development issues. Therefore, women are deprived of their basic rights.

This dual situation is extensive in our society. Women cannot go to school because of insecurity, lack of cultural and moral values among people, and in many cases women cannot go to school and university simply due to shortage of universities and collages in the country.

Most fathers would not allow their daughters to go to Kabul for studying in the university. but boys are allowed. Girls should marry and go to husband's home. This is a reason for inequality between men and women. In Europe mean age for women is 4 years higher than that of men, despite the common saying that men are stronger than women. But in developing countries women have much worse health status due to lack of health facilities. Women are given less attention and are brought to doctors less often. Violence prevents cultural. political and social development of people, and makes them totalitarian. People in traditional societies who grew unill democratic way of thinking are like bicycle riders who push the pedals and bend against the wind coming towards them, for example if you say that the Education Ministry does not have a good building they will say that the honorable Education Ministry does not have a beautiful building. People who were grown in violence have observant language. Contemporary societies have various treaties that are created for some traditions. The problem is that can we commit ourselves to these treaties? I think that the first step in Afghanistan was creating the constitution for Afghanistan, in which some of the cultural and religious principles are included. and some of modern global principles which are in harmony with our cultural principles and values are included too. We can 


\section{Impact of traditional practices on women}

document it as a written treaty. Contemporary treaties are documents and provide the opportunity for participation in civil society. The civil society is a society with law.

In American and European societies, the society is divided into three basic element, that include Economy, which is out of people's control, Government, which executes the power and mediates among people and is not controlled by the people, and Society. Society and the government should have an economy. When the society gets out of economic or government control as a result of struggles for civil society, it was set forth that the society should be something other than economic and political aspects of the government. The citizens should have power, i.e. a citizen must be independent, and should contribute voluntarily in the society, based on civil society values such as brotherhood, cooperation, solidarity. These organizations that are created according to voluntary work and based on above mentioned values may cause growth and development of civil society organizations and the duty of these organizations would be bringing back the control of society under the economic part of the government.

The vacuum in justice, equality and cultural context of the economic part of the government need solidarity. For now, in a society in which about half of it do not participate in the daily political and civil activities due to cultural, traditional and belief problems, existence of a civil society is not much realistic, but we are at the threshold of the process of civil society, and this is a long process, and will continue until human beings exist, and will extend. Women slowly become independent as their education level rise and the economical dependence decrease. Therefore, with these steps the society can grow to a civil society and this is a process that we are at the beginning of it. 


\section{Impact of traditional practices on women}

\subsection{Speech of Mr Qiamuddin Kaschaff, Director Public security dept. of the Supreme Court of Afghanistan, on customs and traditions from Islamic point of view:}

As with other countries of the world, in which Women rights are given in some extent, Islam gives women civil as well as spiritual value too. A person asked the prophet that who should be most respected. and the prophet answered it is the mother who must be respected most. This is the saying of the prophet, not a writer, not a poet,

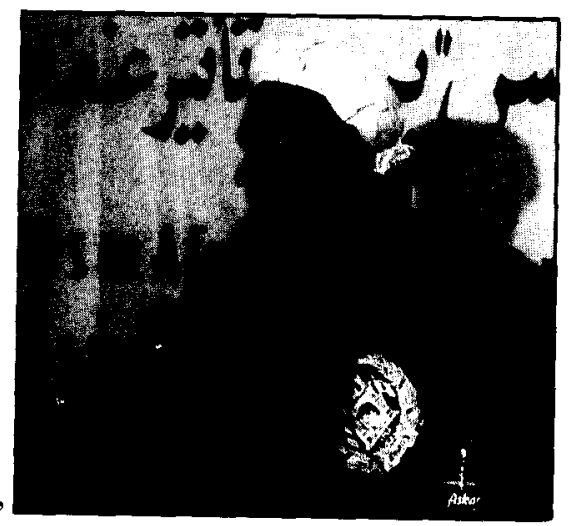
not a scientist and not a philosopher. There is a $\mathrm{rcrsc}$ in the Holly Quran which says "his saying is nothing but revelations we sent him". He has given 3 times more rights to mother than father. In which part of the world women rights are 3 times more than that of men? Of course there is no place where this can be observed. Only in Islam this kind of rights are given to women. The prophet ordered Omar to seek blessing of a person in Madina, who was called Wais Qarani. Omar said he wasn't a Sahabi (person who had talked with the prophet), and this person had not seen the prophet. But the prophet ordered him to seek his blessing and to tell him that the prophet had mentioned him. He went and saw this man, and told him that "you never talked to the prophet but he ordered us to seek your blessings". He said "my mother was very old and weak and I couldn't go to see the prophet because my mother needed me". Please note that how much the prophet gives importance to respecting women, and prefers serving mothers to attending prophet's meetings. Islam is full of these fine cases. 


\section{Impact of traditional practices on women}

Iqbal says "Islam has no flaws in it, it is us who bring the flaws". We shouldn't feature Islam by what Moslems do, but we should study Islam as it is.

Mahr (marriage portion) is women's right, and is mentioned in the Holly Quran and is called Qantar (unlimited goods). Omar was delivering a speech on Mahr and was saying that it was better to have the Mahr lower. But a woman raised her voice and said that "O Omar, you are wrong! God has given us Qantar, why you are asking us to drop this amount?" Omar accepted her objection and said that she was right and "Omar was wrong", despite he was the Caliph of all Moslems in the world, and could reject her objection.

Bad traditions and customs exist even in the $21^{\text {st }}$ century and some of them are worse than those of medieval era. It would not be correct to link every wrong and had tradition with Islam. In Islam a woman has the right to ask her husband to provide a nursing woman for her child, and the husband has to provide it without hesitation. Even if the wife asks for money for her breast milk, husband must pay for it. Is there this kind of rights for women elsewhere? Providing food, home, cloths etc for women is the responsibility of men, while women have the right to work and make capital of their own. In Islam it is not said that women should stay in their homes, but they have the right to work. In 1978 I was with Mufti Mahmood in Pakistan, when somebody asked his about women rights. He said there are many books written on this subject, but I will summarize it in one sentence. I hope you will understand it. Women have that much rights in Islam that if these right were given to them properly, I Mufti Mhamood would ask God to make me a woman! It was really a good answer and he said that if women rights which are entitled to them in Islam are given to them, women would enjoy the most confortable life in the world. 


\section{Impact of traditional practices on women}

Now, some people sell women for money. Is it in Islam? Certainly not. These people make a bad reputation for Islam and this money is haram (illegal) in Islam. as is bribe. The father does not have the right to take money in exchange of his daughter. The bride has the right to use the marriage portion. She can give it to her father. can give it to some one else or just throw it away, or keep it. Is there this tradition in Islam that when some one commits murder or kidnaps as woman then gives his women as an exchange for his crimes, when the jirga (peoples" gathering) ask him to do so? Certainly it is not in Islam. Isn't it burying her alive? Isn t this girl under pressure for the rest of her life? And she is insulted and said to her that she was brought there as and exchange. Islam de ss not support but condemn the act of giving a lady in exchange of her father or brother's crimes. This is certainly against Islamic values.

Also. exchange marriage, in which girls are exchanged for girls or money, is against Islamic teachings. Women are human beings and are not for exchange. Most of problems among families are because of this kind of marriages.

In Afghanistan women are given freedom, which is much more than you would expect. but it is different. In Afghanistan women are seen as respectful people. The limitations set out by Islam are to protect their respect, social values and human rights. Islam broke all negative and bad traditions and customs which existed before, such as burying girls alive, sell them in markets, or having women as house maids. Islam is sent by God to guid us throughout our lives. Every equipment is supplied with a user's manual, in which the ways to operate that equipment is shown. If the equipment is used without consulting with the manual it may be damaged. God has created us and has sent us a guiding manual. 


\section{Impact of traditional practices on women}

which is Holly Quran. If we follow its instructions, we would have a good and respectful life, and if we do not use the guide, we will be losers.

I was the deputy speaker in the constitution loya jirga, and there were a great number of women there. They put me under pressure and said that they wanted more time and opportunity to speak. The same thing was from men too. I'm proud of women for their speeches, activities and responsibilities. They are a bright part of our society. $42 \%$ of women in Afghanistan voted, some of whom were not given permission by their families to work out of home, but men did not stop them from voting. This is a fact, and please look at the constitution and see what is gives you.

At the end I would like to thank Women and Children Rights Research Organization for holding this conference. 


\subsection{Speech of Dr Zekria, member Judiciary and Justice Reform} Commission, on traditions in comparison with law.

I would like to start my speech from this point, that the first relation which links humanity together is society. What is society made of? Society is make of family, nation, tribe, etc.

In a society where there is no law traditions and customs are used as replacement of law to some extent. Traditions and customs are based on beliefs. There is the question of why societies need law? The answer is that societies can go forward with law.

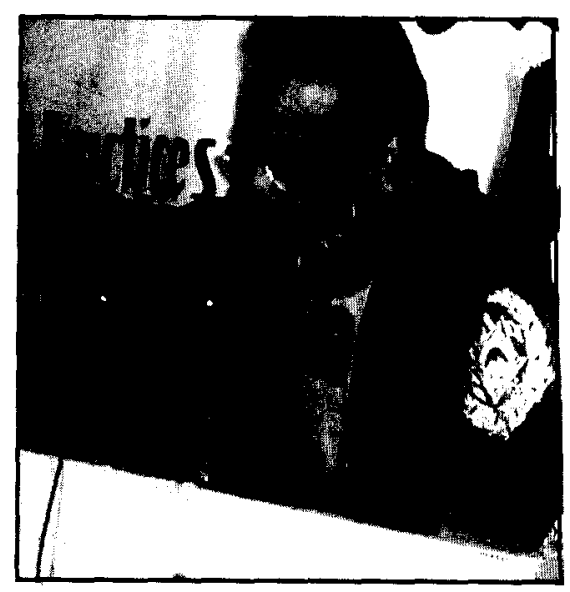

Freedom does not mean that humans are subject to responsibilities, but humans should be ruling the responsibilities. The person who rules the responsibilities is always successful. God made human beings the noblest creature, so that it becomes the ruler of the responsibility, and humans are given authority so that responsibility is governing the society. It means that there must be laws so that by enforcing them the society progress and develop. The other pillar of the society is enforcing and monitoring the law, so that all moral and social laws monitor traditions. For this pillar two monitors are needed, one is external which is police. and the other is internal which is God. Some countries have separated their law from religion. 


\section{Impact of traditional practices on women}

If you have noticed when a crime is committed or a murder is committed, murderer's family is always seen as the murderer in the eyes of the murdered family. In fact these violence create tradition and sometimes the violence can destroy a society.

As the speakers said, we are moving from a simple society towards a complex one. in which every individual has responsibility. Some of traditions are enforced as laws. Police was responsible for monitoring, but now military, security and executive forces govern the society in a complex manner. Therefore, the 2 phenomena we needed for the society were: legislative and judicial forces. Despite existence of Shariah in Afghanistan, the government has not been able to enforce it in the country. Today, there are traditions in our country that do not relate to Islam. The other factor that had negative impact on our society has been more than 20 years of war and conflict, and tyranny and violence was ruling the country. We have another problem too. Now we are not in isolation from the world as we were 100 years ago. Now we have links with other parts of the world and the world is looking at us, and affects us. The effects had their influence on the way we wear cloths, and our livelihoods. We had a strong cultural background but today western culture is dominating our society day by day.

When we try to bring reforms in our laws we have to know which of them are related to our culture and which is not, as Mr Manawi and Kachaff said.

We must recognize our good traditions and keep them. According to statistical data in the world, 2 out of 3 marriages break away, every minute a woman is abused or raped in some western countries. But fortunately in our country, due to 


\section{Impact of traditional practices on women}

good traditions and customs less men divorce their wives and respect marriage relationships, which in my opinion a good tradition.

It should be pointed out that violence against women is not exclusive to Islamic societies. At the end I would like to encourage who established this organization. This is the way to struggle because you have to take your rights, nobody will give it to you.

Thank you 


\section{Impact of traditional practices on women}

\subsection{Speech of Ms Amiıa Afzali, member Human Rights Independent Commission, on traditions from international law point of view for women.}

Greetings my brothers and sisters, and thanks for Women and Children Rights Research Organization who have held this conference. We really benefit from these conferences. The subject given to me was women rights violations in bad traditions. We do not have any problem with the present laws in our country and society, but some of our laws should be refined so that bad traditions can be stopped. If our constitution and civil laws are not enforced, they remain on paper. We are Moslems but unfortunately we never follow Islam. especially our society conduct is un-islamic. One of the bad traditions here is forced marriages. In Islam forced marriage is unlawful. If both sides, i.e. bride and groom are not agreed with the marriage. then this marriage is not legal. Today, most of the problems which end up in violence, according to reports coming to Human Rights Commission. are rooted in forced marriages. I want to talk about present situation. we will see if the bad tradition roots in our society and history and what place is given by Islam to women.

With the start of Interim government and approval of constitution positive changes in the constitution came into view. I was one of the nembers for the Constitution Commission. When we wrote our opinion on paper we did not believe that this could be taken in to consideration. because the traditions have strong influence in the society. It will

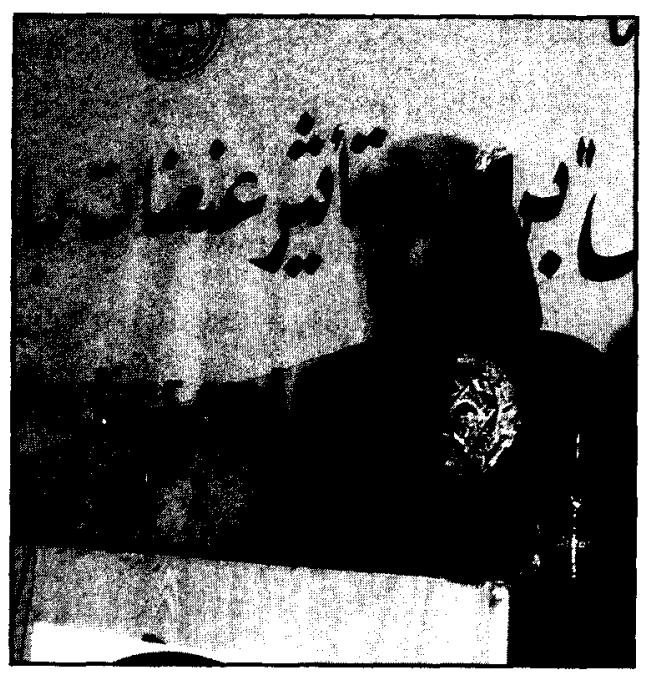




\section{Impact of traditional practices on women}

take a long time that changes take place.

I think the laws alone cannot be enough for stopping violence against women. We must increase level of knowledge in the society by public awareness, and provide economic growth for women. If women are given part in home economy it will be a good pace for them. Women in home have responsibility of managing the house and look after children. If we analyze it this is a big problem, that we can relate it to economic matters, but unfortunately men in our society do not think about this and always say that women must cook and manage the house. While the prophet helped his wife in home, it is a taboo in our society that a man washes dishes or cleans the house. Most men do not respect their wives despite this division of works. When the man comes home from work expects his wife to respect him. He should also respect his wife because she also worked hard in home. This brings friendship between them. But most men expect too much form their wives. which eventually cause violence.

When the level of knowledge in the society increase and men and women understand their responsibilities in the family, these problems will disappear. I wanted to give you brief reports of human rights abuses during the years of interim and transitional governments of Afghanistan. These abuses are registered in the Independent Human Rights Commission but our data are neither accurate nor proven, because most of women in our society do not have access to human rights commission. Most of the cases referred to us are from Kabul, from which more than 60 eases are forced marriages, some of which ended up with divorce and about 100 cases in the last 6 months were deferred to public courts by the commission. Some of cases were solved by negotiations with both sides. Some of women think it is not right to go to the courts or human rights commission, 


\section{Impact of traditional practices on women}

and accept suffering in bad conditions. Therefore, it is possible that a great number of the problems cannot be registered.

Regarding the problems of abuse in provinces we will talk about eastern province of Nangarhar and western province of Herat. For example, in Herat where people have high cultural level, suicide among women and girls is high. In the last 6 months more than 180 cases of suicide is registered form Herat, from which about 100 cases were self burning and some the cases were suicide by toxic drugs. About $70 \%$ of these cased ended up with the death of the victims. The reason was either they died before they reached hospital or they were not brought to hospital al all. These data show the extent of violence against women. The registered cases form Jalalabad show that 80 suicide cases by opium, form which 70 of them died. 39 cases of self burning and many cases of beating were registered. These data show how much violence is committed against women and they were forced to commit suicide. There are many cases that the husband became angry with his wife because she had put color on her hair, a wife was blinded by her husband because she looked at some one, and a friend to me that a man cut his wife's lips because she kissed her son-in-law.

These cases were registered during this year, and show the degree of violence against women, which is caused by low level of knowledge among women and bad tradition in the society, because most women are not aware of their rights. At the end I hope that holding these conferences help women to raise their voices and solve their proble 


\section{Impact of traditional practices on women}

1.8. Speech of Ms Najia Zewari, representative of UNIFEM, on UN commitments of women rights.

\section{We are part of a historical process}

As we are at the threshold of fighting

Violence against women week, struggle against bad traditions and customs is part of this fight; it would be rational to look at the global events in relation with women rights, and mention some of historical documents and events in this context:

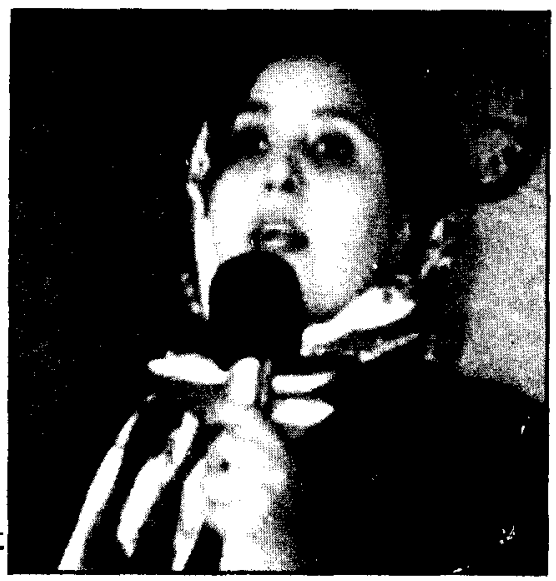

1. Women 's day was marked for the first time on March $8^{\text {th }} 1911$.

2. in 1946 UN commission on women conditions was established.

3. In 1946 UN Human Rights declaration was approved.

4. In 1949 convention on prohibition of human traffic and prostitution was approved, which was enforced since July 25, 1991.

5. On December 20, 1952 treaty of Political Rights of Women was approved by theUN, and was enforced since July 7, 1954.

6. On January $29,1957 \mathrm{UN}$ approved a treaty for the citizenship of married women, which was enforced since August 11, 1958.

7. On November 25, 1960 Miraol Sisters political activists were killed by the dictator Torjilo in Dominican Republic. Since 1981 day of violence against women is celebrated worldwide.

8. On December 14, 1960 a treaty against discrimination in education was approved, which was enforced since May 22, 1962. 


\section{Impact of traditional practices on women}

9. In 1961 Paraguay was the last Latin American country which gave voting right to women.

10. On November 7. 1962 treaty on youngest age for marriage was approved. and was enforced since December 9, 1964.

11. In 1964 treaty on employment was approved and is enforced since 1966.

12. In 1967 Iran approved a law which allows women to support the family, and work without husband permission.

13. On April 22 to May 131968 International conference on human rights was held in Iran.

14. In early 1970 marches called "re-take the nights" were commenced for the first time by women.

15. On December 14, 1974 convention on protecting the women and children in emergency situations and military conflicts was approved.

16. In 1975 this year was named Year of Women.

17. On March 4-8 first international court on crime against women was held in Belgium.

18. In 1976 UN decade for women began.

19. On December 18, 1979 convention on eradication of discrimination against women was approved by $\mathrm{UN}$ assembly and was enforced since December 3, 1981.

20. Form 6 to 15 April international workshop on fight against traffic and sexual slavery of women was held in Holland.

21. In 1985 a treaty against torture and other forms of tyranny and on commutation in punishment was approved and enforced since 1987.

22. International Women conference was held in Kenya from 15 to 26 July 1985. 


\section{Impact of traditional practices on women}

23. In December 6, 1984 in Canada, an angry man killed 14 women technicians because they were working in a field belonged to men.

24. From November 25 to December 10 the first ever 16 day campaign on violence against women was held globally and the women's human rights campaign started.

25. In 1992 rape was used as a war weapon, whose victims were thousands of women in former Yugoslavia.

26. In New Zealand 100 years of women struggle for their right to vote in the political elections in that country was celebrated. New Zealand was the first country to give women right to vote.

27. On 15-25 June. 1993 International Human Rights conferences and International Court on human rights violations against women was held in Austria and about 500000 signatures were collected and submitted to whir.

28. On October 6, 1993 with integration of Bahamas in the convention on obliteration of discrimination against women of Latin America and Caribbean. it was the first region that all of the countries signed the convention.

29. In December 1993 UN general assembly approved a resolution on violence against women.

30. On December 20, 1993 UN general assembly approved a resolution on appointing a human right commissioner. UN general assembly asked the commissioner to prepare working plan for the human rights decade on education to be announced in $49^{\text {th }}$ session of the general assembly.

31. In 1957 in the fourth international women conference, UN announced the year 1975 as the international year for women. 


\section{Impact of traditional practices on women}

32. The first international women conference was held in Mexico from June 16 to July 2. Its theme was Equality, Development and Peace.

33. UN announced 1976 to 1985 as the decade for women.

34. The second international women conference (mid women decade) was held in Copenhagen from July 14 to 26, 1980.

35. In 1985 third international women conference was held in Nairobi, Kenya from July 15 to 26 . Its aim was strategies for future development of women towards 204.

36. Forth international women conference was held in Peking, China from September 4-15. Its outcome was Peking Declaration and practice of Peking Movement.

37. Special part of UN general assembly for women (2000):

Gender equality, development and peace for $21^{\text {st }}$ century in New York held on June 5-9. Its outcome was a political resolution and related documents. More measures and initiatives to make Peking Movement operational. 


\section{Annex 2:}

\section{Women and Children Legal Research Foundation (WCLRF) \\ Declaration of the Conference on \\ "Impact of traditional Practices on Afghan Women" \\ 22 - 24 November 2004 \\ Kabul-Afghanistan}

\section{Any kind of violence against women is condemned!}

We. the participants of the Conference on "Assessment of Traditions' Impact on Afghan Women", representing almost all of Afghanistan and accepting that all around the world women and girls are the most vulnerable people; and in the memorial of all those women and girls who have been the victim of violence; having Islam's supportive and strong position as the main backbone; also by considering the support of Afghan Constitution and all other prevailing laws and regulations: keeping in mind the commitment of Afghan Government to the International Declaration of Human Rights, Islamic Declaration of Human Rights. The convention on elimination of discrimination against women and other valuable international documents regarding the support for women's equal rights; stating that most of Afghan local traditions have become the main factors to the propagation of violence in Afghanistan; understanding that dissemination of information about the impact of traditions on afghan women under the effective and continuous support of the Government and Judicial institutions could become a key element in decreasing and elimination of one type of violence against women; and with the attention to the importance of women and girls participation in the social life of societies; conclude the following articles as the main demands of women and girls for reducing violence against them. and ask for solemn attention from the part of government, its related institutions and international communities in this regard: 


\section{Impact of traditional practices on women}

1- Since, setting and enforcing the law has a determinant role in establishing the citizens' rights and freedom, it is necessary that all actions and movements which, in the name of tradition, are imposed on afghan women and girls should be considered as the source of violence and declared as violation of the law and the perpetrators be punished.

2- As the highest justice implementing authority, the judiciary system in cooperation of other institutions concerning the citizen rights, based on legal and jurisprudential adjudications should pay an axial role in elimination of those traditions which are determined as the source of violence and the violators must be accordingly penalized.

3- The role of the executive authority, in particular the law enforcement institutions such as police, prosecuting authority, Ministry of Justice and other related stakeholders, is very effective and constructive for the implementation of law and detection, persecution, inspection of crimes originated from traditions: consequently, these authorities must take serious steps to prevent the tradition based violence against women and girls and arrest the criminals.

4- As the local Jirgas ( traditional gathering of afghan communities in southern Afghanistan) and Shuras ( local counseling board made up of elders, influencing members and trustees of the community) are the most important structures to implement and enforce the traditions and the decisions and decrees made by them is effectively executed, we suggest:

a) It is convenient that for the choosing implementation approaches and decision making. during the Jirgas; a specific framework and effective principles be projected, based on which the people included in the Jirgas feel responsible and committed towards their decisions. 


\section{Impact of traditional practices on women}

b) In order to pave the way for reducing and elimination of violence against women, their participation in the above mentioned structures should be facilitated using the different existing programs as National Solidarity Program

5- Emphasizing on our people's strong religious beliefs and the prominent stance of religious scholars in elucidating public opinion, we request from all Scholars and clergy men that:

a) They help people to broaden their view and making them understand the existing differences among the traditions and religious believes: and through elimination tradition based violence, they support afghan women and girls.

b) They explain canonical rights of women and girls to afghan society and they emphasize on the obligation to respect these rights.

6- Media has a particular role in raising public awareness in defending the rights of individuals and groups; knowing that women and girls are bearing much violence induced by wanted and unwanted traditions; we aspire that Afghan Media provide a support for this by undefended group which has been victimized by local traditions broadcasting the voice of afghan women and girls.

7- Literacy and access to education is the most basic means to support women and girls against the violence; so we are confident that any kind of measures taken for the preparation of facilities to improve education and literacy among women and families. it would reduce the violence many fold. 


\section{Impact of traditional practices on women}

8- $\quad$ Seeing that poverty is considered one of the basic factors of violence and in addition, lack of access to material advantages make women and girls more needy and undefended; we have to take some specific and defined initiations to make sure the economical independence of women and girls.

9- Until now, national human rights supporting institutions, civil society, national and international non-governmental organizations and UN agencies have played an important and effective role in elimination of encroachments and violations against various vulnerable groups and in particular women; now since these organizations and institutions being extensively active inside afghan society, and by using their experience, can release women and girls from all violations caused by local traditions and customs.

10- We, the participants of the conference on "Assessment of Traditions Impact on Afghan Women' representing various provinces and gathered in Kabul the capital of our country, have ratified this ten-article declaration and look forward to seeing the responsible authorities provide the needed support, for afghan women and girls against the traditions causing violence, based on the proposed suggestions in this declaration. 
Impact of traditional practices on women

Annex: 3 -Conference Agenda

Women and Children Legal Research Foundation (WCLRF)

Conference on "Impact of traditional Practices on Women

22- 24 November 2004

Agenda:

First Day:

Time

Topic

Speaker

09: $00-09: 05$

Reading holy Quran

$09: 05-09: 30$

Introduction of Participants

$09: 30-10: 10$

Introduction of WCLRF \&

objective of Confernce

Hangama Anwari

$10: 10-10: 40$

Tea Break

$10: 40-11: 00$

overview of traditional Prctices in

Afghanistan

Mr. Farid Hamidi

$11: 00: 11: 30$

Traditional Pratcices and Violance

Against Women

Dr. Suraya Subhrang

$11: 30-12: 00$

Court procedure to wards

Traditional Practiceds

Mr. F. Manawi

$12: 00-12: 30$

impact of traditional practices

On society

Dr. Dadfar 


\section{Impact of traditional practices on women}

12:30 - 01:30 lunch \& Pray break

1:30-02:00 Traditional practices \& Islam Mr. Kashaf

02:00 - 02:30 Traditioanl practices and laws Dr. Zekria

02: 30 - 03:00 Traditional practices and int'l norms Ms. Amena Afzali

03:00 - 03:30 UN commitment towards women Right Ms. Najia Zewari

03:30 - 04:00 General discussion\& $\mathrm{Q}$ and $\mathrm{A}$ and conclusion

\section{Second day:}

09:00-09:10

Review of the last day

$09: 10-10: 30$

Group Work "traditional practices and its impact on women"

Facilitators

10:30-11:00 Tea break

11:00-12:30 Presentation of group work

$12: 30-01: 30$

Launch and Pray break

$1: 30-04: 00$

4 working groups "on solutions for traditional practices

applied on women"

Facilitators

\section{Thired day}

09:00-09:10 review of the last day

09:10 - 10:30 movies on traditional practices (BAD \& Stonning)

10:30 - 11:00 Tea Break

11:00 - 12:30 discussion on content of draft resolution

12:30 - 01:30 Launch \& Pray Break

01:30-04: 00 announcing the resulotion

Lunching the report on Bad practice

Distribution of appreciation letter 


\section{Impact of traditional practices on women}

Annex: 4

List of Participants

\begin{tabular}{|c|c|c|c|}
\hline No & Name & Province & Address \\
\hline 1 & $\begin{array}{l}\text { Masooda } \\
\text { Samadi } \\
\end{array}$ & Kabul & AIL \\
\hline 2. & Roshan Seran & Kabul & THRA \\
\hline 3 & KARIMA & KABUL & WJA \\
\hline 4 & AZIZA & KABUL & SUPREME COURT \\
\hline 5 & SHEMA & KABUL & MINISTRY OF CULTURE \\
\hline 6 & NAZEFA & KABUL & MOJ \\
\hline 7 & ROSHAN & KABUL & LITRACY DEPARTMENT \\
\hline 8 & SAKEENA & KABUL & $\begin{array}{l}\text { COUNCIL OF KABUL } \\
\text { RESEDENCE }\end{array}$ \\
\hline 9 & RAHIMA & KABUL & MINISTRY OF TRIBELS \\
\hline 10 & MALALI & KABUL & MINISTRY OF CULTURE \\
\hline 11 & $\begin{array}{l}\text { WORANGA } \\
\text { SAFI }\end{array}$ & KABUL & MINISTRY OF EDUCATION \\
\hline 12 & NOOR JAN & KABUL & KABUL UNIVERSITY \\
\hline 13 & FARZANA & KABUL & ACADEMY OF SINCE \\
\hline 14 & MUSLEMA & KABUL & MINISTRY OF INTERIOR \\
\hline 15 & GULALI & KABUL & WJA \\
\hline 16 & SHAH JAN & KABUL & MINISTRY OF JUSTICE \\
\hline 17 & MUZHDA & KABUL & US EMBASSY \\
\hline 18 & HAMED & KABUL & ACADEMY OF SINCE \\
\hline 19 & $\begin{array}{l}\text { ASEFA } \\
\text { KAKER }\end{array}$ & KABUL & SUPREME COURT \\
\hline 20 & FAWZIA & KABUL & MINISTRY OF EDUCATION \\
\hline 21 & NAJIBA & KAB,UL & HEWAD PUBLICATION \\
\hline 22 & MAH GUL & MAZAR & $\begin{array}{l}\text { ATTORNEY GENERAL } \\
\text { OFFICE }\end{array}$ \\
\hline 23 & $\begin{array}{l}\text { PARWEN } \\
\text { RAHMATI }\end{array}$ & KUNDUZ & SCHOOL TEACHER \\
\hline 24 & $\begin{array}{l}\text { SURAYA } \\
\text { DAQIQI }\end{array}$ & HERAT & AIHRC \\
\hline 25 & ZAHRA & BAMYAN & $\begin{array}{l}\text { HEAD MASTER OF } \\
\text { SCHOOL }\end{array}$ \\
\hline 26 & ZIA GUL & JALAL ABAD & HEAD MASTER \\
\hline
\end{tabular}




\section{Impact of traditional practices on women}

\begin{tabular}{|c|c|c|c|}
\hline 27 & FAHIMA & KANDAHAR & HEAD OF HIGH SCHOOL \\
\hline 28 & $\begin{array}{l}\text { ENG. YAR } \\
\text { MUHAMAD }\end{array}$ & ANDKHWI & SAVE THE CHILDREN US \\
\hline 29 & HABIBA & ANDKHWI & SAVE THE CHILDREN US \\
\hline 30 & $\begin{array}{l}\text { NEDA } \\
\text { KEHANI }\end{array}$ & BAGHLAN & FCCS \\
\hline 31 & $\begin{array}{l}\text { FAHIMA } \\
\text { SADAT }\end{array}$ & SHEBERGHAN & FCCS \\
\hline 32 & KHADIJA & SAMANGAN & FCCS \\
\hline 33 & PARDESA & KUNAR & $\begin{array}{l}\text { WOMEN AFFAIR } \\
\text { PROVINCIAL } \\
\text { DEPARTMENT }\end{array}$ \\
\hline 34 & $\begin{array}{l}\text { M. NAWAZ } \\
\text { SAFI }\end{array}$ & KUNAR & ELDER OF COMMUNITY \\
\hline 35 & $\begin{array}{l}\text { M. AREF } \\
\text { RAWAN }\end{array}$ & GHAZNI & CULTURAL ASSOCIATION \\
\hline 36 & AB. SAMI & BADGHES & \begin{tabular}{|l} 
COMMUNITY \\
REPRESENTATIVE
\end{tabular} \\
\hline 37 & ZALIFA & PANJSHEER & WADKHEL HIGH SCHOOL \\
\hline 38 & M.HASHIM & FARAH & HABITAT \\
\hline 39 & $\begin{array}{l}\text { MUSAFER } \\
\text { RAEES KHEL }\end{array}$ & JALAL ABAD & ACADEMI OF SINCE \\
\hline 40 & MARIA & TAKHAR & TAKHAR HIGH SCHOOL \\
\hline 41 & M. DAWOD & KHUST & $\begin{array}{l}\text { COMMUNITY } \\
\text { REPRESENTATIVE }\end{array}$ \\
\hline 42 & MAREAM & FARAH & FARAH HIGH SCHOOL \\
\hline 43 & AB. SAMAD & MAIMANA & $\begin{array}{l}\text { COMMUNITY } \\
\text { REPRESENTATIVE }\end{array}$ \\
\hline 44 & ANISA & MAIMANA & $\begin{array}{l}\text { WOMEN } \\
\text { REPRESENTATIVE }\end{array}$ \\
\hline 45 & HAMED & LOGAR & $\begin{array}{l}\text { COMMUNITY } \\
\text { REPRESENTATIVE }\end{array}$ \\
\hline 46 & $\begin{array}{l}\text { MAHMOD } \\
\text { RAHGUZAR }\end{array}$ & TAKHAR & AWC \\
\hline 47. & $\begin{array}{l}\text { MS. MEHRO } \\
\text { HAMID }\end{array}$ & KABUL & JRC \\
\hline 48 & AISHA & BADGHES & CIVIL SOCIETY \\
\hline 49 & FAWAD & KABUL & \begin{tabular}{|l} 
JOURNALIST \\
\end{tabular} \\
\hline 50 & MUZHDA & KABUL & US EMBASSY \\
\hline
\end{tabular}




\section{Impact of traditional practices on women}

\begin{tabular}{|l|l|l|l|}
\hline 51 & $\begin{array}{l}\text { GENERAL } \\
\text { AZIZA }\end{array}$ & KABUL & MINISTRY OF INTERIOR \\
\hline 52 & $\begin{array}{l}\text { ADELA } \\
\text { KAWOSI }\end{array}$ & KABUL & JOURNALIST \\
\hline 53 & KARIMA & KABUL & $\begin{array}{l}\text { BI BI HAWA HIGH } \\
\text { SCHOOL }\end{array}$ \\
\hline 54 & $\begin{array}{l}\text { SHAHEDA } \\
\text { BARMAL }\end{array}$ & KABUL & AIHRC \\
\hline 55 & FATANA & KABUL & AIHRC \\
\hline 56 & $\begin{array}{l}\text { KHALED } \\
\text { YOUSUFZAI }\end{array}$ & KABUL & WCLRF \\
\hline 57 & $\begin{array}{l}\text { S. MASOOM } \\
\text { BADAKHSH }\end{array}$ & KABUL & WCLRF \\
\hline $\mathbf{5 8}$ & SAFIA AMIRI & KABUL & WCLRF \\
\hline 59 & $\begin{array}{l}\text { FAWZIA } \\
\text { MURADI }\end{array}$ & KABUL & WCLRF \\
\hline 60 & $\begin{array}{l}\text { NELOFAR } \\
\text { QADERI }\end{array}$ & KABUL & WCLRF \\
\hline 61 & MALIHA MIR & KABUL & WCLRF \\
\hline 62 & ABEDA & KABUL & WCLRF \\
\hline 63 & BASER & KABUL & WCLRF \\
\hline 64 & $\begin{array}{l}\text { HAMID } \\
\text { REZAQ }\end{array}$ & KABUL & WCLRF \\
\hline 65 & WAZHMA & KABUL & WCLRF \\
\hline
\end{tabular}




\section{Impact of traditional practices on women}

Annex 5: Facilitators:

1. Najia Hanifi

2. Shela Samimi

3. Jawed danshyar

4. Zakia

Annex 6: task force

1. Najia Hanifi

2. S, Masoom Badakhsh

3. Kadeja

Annex 7: Speakers

1. Dr. Suraya Subhrang

2. M. Farid Hamidi

3. Fazel Ahmad Manawi

4. Dr, Rangeen Dadfar Spanta

5. Qeeamulldin Kashaf

6. Dr. Zekrea

Commission

7. Amena Afzali

8. Najia Zewari
Arezo Office

AWN

AIHRC

UNAMA

Arezo office

WCLRF

Ministry of women affairs
Deputy Minister, MoWA

Commissioner, AIHRC

Deputy Chief Justice, Supreme Court

Kabul University

Head of civil affairs, supreme Court

Commissioner, Judicial Reform

Commissioner, AIHRC

Senior Program Officer UNIFEM 


\section{Impact of traditional practices on women}

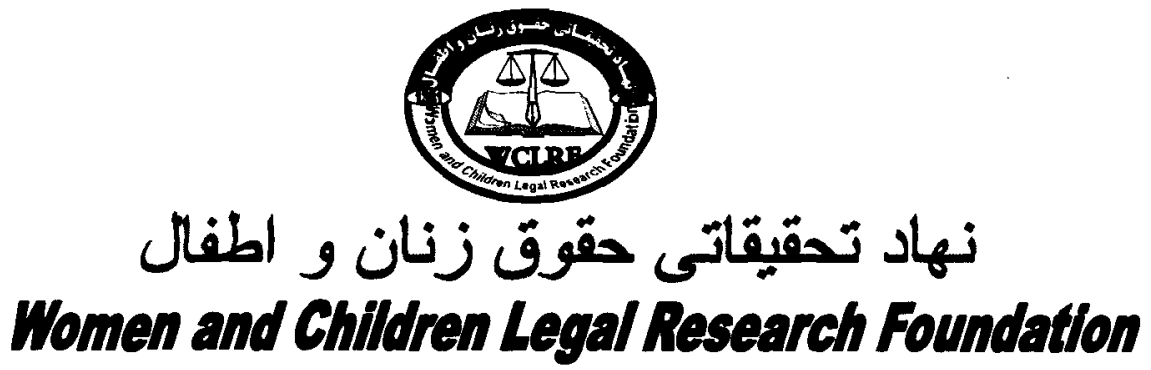

Annex 8(a)

Introduction Form:

Nomunies biography:

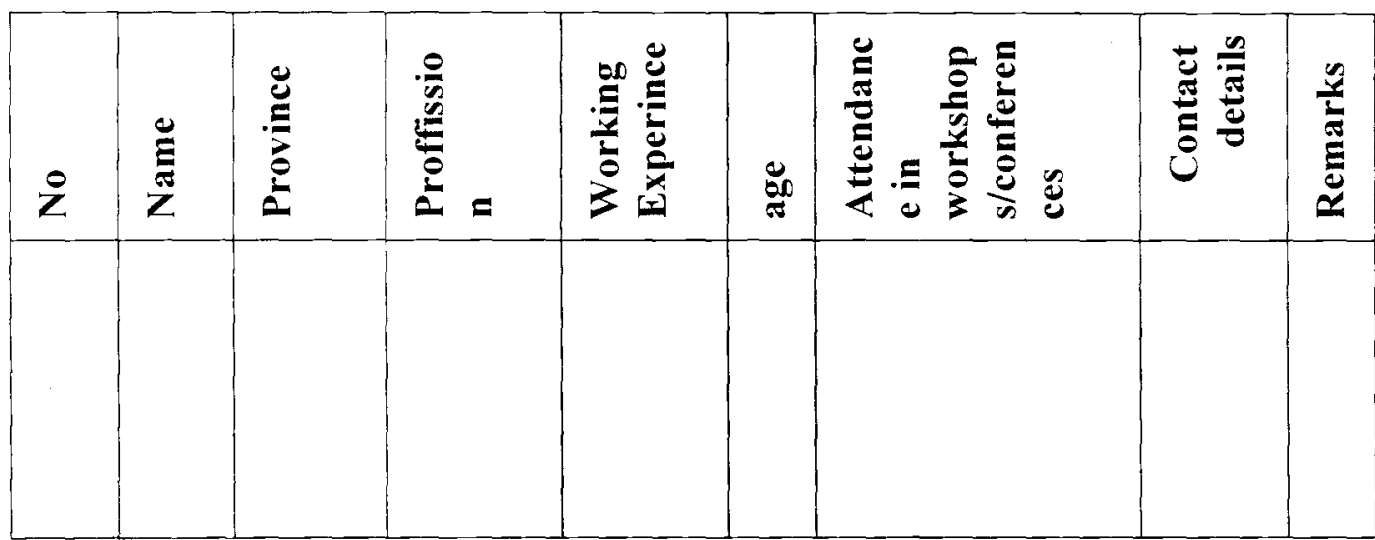

Person who nominates:

\begin{tabular}{|l|l|l|l|l|}
\hline $\begin{array}{l}\text { No } \\
\ddots\end{array}$ & Name & Posission & $\begin{array}{l}\text { Tel/ email } \\
\text { contact }\end{array}$ & Remarks \\
\hline & & & & \\
& & & & \\
\hline
\end{tabular}

Note:

1. The person can not nominate him/ her self

2. Nomunies should be aware of the traditional practice applied in their area,

3. Nomunies should be a well known person

4. Male candidates should be member of local councils 
Annex 8(b):

\section{Concept Paper}

Traditional practices are playing a very important role in Afghan Society, and it applies in many different ways. Researches have shown that most of the traditional practice are applied by man and applied on the femal devision of the society.

In order to identify these types of traditional practices and find ways of overcoming such practices, the WCLRF has paln to conduct a 3 day workshop with the participation of participants from at least 20 provinces of the country.

Dear Nomunie!

Please answer to the following question as a first step forward to struggle against violence against women:

1. What are traditional practices?

2. What type of traditional practices is applied in your area?

3. What are the positive and negative traditional practices in your point of view?

4. What is your proposal to overcome negative practices?

5. To wide sperate the positive traditions what should we do?

6. What will be the impact of your participation in the coming conference?

Note:

Each nomunies should fill the questionnaire

Our address: $3^{\text {rd }}$ macrorayan, Block $4^{\text {th }}$, Apt $19^{\text {th }}$, Kabul-Afghanistan.

Tel: 070288504,070041843 
th:

$R$

3.164

$W C L$

12692

exis

Women and Children Legal Research Foundation

Add: 3rd Macroryan Block \# 4rd Apt\# 19th, Kabul- Afghanistan

E mail: wclrf@yahoo.com

Ph:070041843-070288504 